\title{
Toward First Amendment Limitations on the Introduction of Evidence: The Problem of United States v. Rosenberg
}

\author{
Peter E. Quint ${ }^{\dagger}$
}

Since the June evening twenty-four years ago when the government of the United States "rang down the curtain"1 on the lives of Julius and Ethel Rosenberg, ${ }^{2}$ their case has posed perplexing difficulties for those concerned with the American judicial system and its response in times of political stress. ${ }^{3}$ Coming in the middle of the Korean War and less than two years after the Soviet Union unexpectedly exploded its first atomic device, the Rosenbergs' trial for conspiracy to commit atomic espionage raised, in sharpest form, the type of emotional issues most likely to distort the judicial process. In time, perhaps, questions of the defendants' guilt or innocence, and other factual issues still the subject of bitter dispute, may assume a predominantly historical importance. Yet the fundamental problems of the case, as an exemplar of judicial process in a time of extraordinary stress, will continue to demand critical scrutiny. Of the numerous problems of judicial process raised by the Rosenberg case, there is one of continuing importance that has eluded cogent treatment.

$\uparrow$ Professor of Law, University of Maryland.

1. See Rosenberg v. United States, 346 U.S. 273, 310 (1953) (Frankfurter, J., dissenting from vacation of stay of execution).

2. The principal opinions in United States v. Rosenberg are reported at $195 \mathrm{~F} .2 \mathrm{~d} 583$ (2d Cir.), cert. denied, 344 U.S. 838 (1952) (affirming judgment of conviction); 108 F. Supp. 798 (S.D.N.Y.), aff'd, 200 F.2d 666 (2d Cir. 1952), cert. denied, 345 U.S. 965 (1953) (denial of petition for order to vacate and set aside convictions and sentences); 346 U.S. 273 (1953) (vacating stay of execution).

3. The problems of the Rosenberg case have evoked an extensive literature. Legal aspects of the case prompted early law review commentary: Note, The Rosenberg Case: Some Reflections on Federal Criminal Law, 54 ColvM. L. REv. 219 (1954) [hereinafter cited as Columbia Note]. Among other discussions that appeared in the years immediately following the trial were: S. Fineberg, The Rosenberg Case (1953); O. Pilat, The Atom Spies (1952); W. Reuben, The Atom Spy Hoax (1955); M. Sharp, Was Justice Done? (1956); J. Wexley, The Judgment of Julius and Ethel Rosenberg (1953); Mann, Book Review, 67 YALE L.J. 528 (1958).

The publication of WV. \& M. SchNeIR, Invitation to AN INQUEST (1965) stimulated renewed interest in the Rosenberg case. See Bickel, Book Review, Commentaky, Jan. 1966, at 69; Boudin, Book Review, 76 Yale L.J. 254 (1966); Pitofsky, Book Review, 66 Colum. L. Rev. 608 (1966). More recent discussions include L. Nizer, The Implosion Conspiragy (1973) and memoirs by the Rosenbergs' sons, R. \& M. MeEropol, WE ARE Your SoNs (1975), and by Morton Sobell, a co-defendant, M. Sobell, ON Doinc Time (1974). 
At the Rosenbergs' trial the Government introduced evidence that the defendants were members of the Communist Party of the United States and that Julius and Ethel Rosenberg had expressed a "preference" for the Soviet form of government over that of the United States. Many of the statements and associations of the Rosenbergs, so introduced into evidence, clearly represent speech and association protected by the First Amendment. It is reasonable, therefore, that First Amendment doctrine should be considered in determining whether such evidence should be admitted. Yet the bearing of the First Amendment on the admissibility of evidence of unpopular political speech or association to prove a nonspeech offense has received little attention. ${ }^{4}$

4. First Amendment limitations on the introduction of evidence are discussed, in general terms, in T. EMERson, The Systex of Freedom of ExPression 405.07 (1970), and, with respect to conspiracy prosecutions, in Note, Conspiracy and the First Amendment, 79 YALE L.J. 872, 894-95 (1970). For discussion of evidentiary problems in the Rosenberg case, without mention of the First Amendment, see Columbia Note, supra note 3, at 223-28; Pitofsky, supra note 3, at 613-14.

The introduction of evidence of spech and association in the Rosenberg case was by no means unique. In celebrated murder trials in Pennsylvania in the 1870s, evidence was introduced to show that the defendants were members of a secret organization (the "Molly Maguires") that numbered murder of political opponents among its purposes, in addition to more general political agitation. See Hester v. Commonwealth, 85 Pa. 139, 155-56 (1877); Carroll v. Commonwealth, 84 Pa. 107, 124-25 (1877). Similarly, in the trial of anarchists for conspiring to commit the famous Haymarket bombing, voluminous evidence of their political views and associations was entered into evidence. Spies $v$. People, 122 Ill. 1, 119-27, 12 N.E. 865, 923-27 (1887).

Another well-known historical instance occurred in the trial of Sacco and Vanzetti. In that case the prosecution argued that the defendants' suspicious actions at the time of their arrest showed "consciousness of guilt" of murder. The defendants responded that their actions actually reflected fear of mistreatment and deportation, the fate of many radicals during the notorious Palmer Raids then in progress. Under the pretext of determining whether defendants were in fact radicals, as they claimed to be, the prosecution subjected defendants to sustained and inflammatory cross-examination concerning their political views and associations. See F. Frankfurter, The CaSE of SACCo AND VINZETTI 35-62 (1927). On appeal the cross-examination was found not to have been improper, particularly in light of the trial court's instruction to the jury that the " 'radical as well as the conservative" is entitled to equal treatment under the law. Commonwealth v. Sacco, 255 Mass. 369, 439, 151 N.E. 839, 856 (1926). For similar cases arising in this period, see Maki v. United States, 12 F.2d 668 (9th Cir. 1926) (considering introduction of evidence suggesting that defendants were members of Industrial Workers of the World) and Pcople v. Tanner, 36 Cal. App. 20, 171 P. 439 (1918) (same).

During and immediately after World War II evidence of the pro-Nazi views and associations of defendants was introduced in prosecutions for conspiracy to commit espionage, United States v. Molzahn, 135 F.2d 92, 97 (2d Cir.), cert. denied, 319 U.S. 774 (1943), and for treason, United States v. Haupt, 152 F.2d 771 (7th Cir. 1945), aff'd, 330 U.S. 631 (1947). In the Cold War period, evidence of defendants' Communist Party membership was introduced in cases involving conspiracy to obstruct justice, United States v. Brothman, 191 F.2d 70 (2d Cir. 195l); see J. WExLEY, supra note 3, at 218-19, and perjury, United States v. Perl, 210 F.2d 457, 461 (2d Cir. 1954). In another case of the period, evidence of Communist Party affiliations was introduced in prosecutions involving picket-line violence, Commonwealth v. Truitt, $369 \mathrm{~Pa} .72,79,85$ A.2d 425, 428 (1951) (reversing conviction for affray because evidence of Communist activity inadmis- 
Since the Rosenberg case presents the First Amendment problems in an elaborate and suggestive form, an analysis of the evidentiary rulings in that case provides a convenient focus for a broader discussion of the underlying constitutional issues. Consequently, Part I of this article will examine the operation of the traditional evidentiary test in United States v. Rosenberg. Part II will then argue that the First Amendment requires a more stringent exclusion of evidence of the defendant's protected speech and association than is presently afforded by prevailing evidentiary standards. Finally, Part III will propose a First Amendment test for the exclusion of evidence and will conclude with suggestions about the application of that test to specified classes of evidence. ${ }^{5}$

\section{Evidence of Speech and Association in United States $v$. Rosenberg}

In March, 1951, Julius and Ethel Rosenberg were tried for conspiring with others to deliver military secrets of the United States to the Soviet Union. ${ }^{6}$ Morton Sobell was indicted as a co-conspirator.

sible). In United States v. Soblen, 301 F.2d 236 (2d Cir.), cert. denied, 370 U.S. 944 (1962), a prosecution for conspiracy to commit espionage on behalf of the Soviet Union, the defendant's membership in the "Trotskyite wing of the German Communist Party in 1919" was held properly admitted as "relevant background ... to show the motivation and community of interest of the conspirators." Id. at 240.

Similar issues were raised in well-known prosecutions in the 1960s. In the trial of the so-called Panther 2I for conspiracy to bomb department stores in New York City, the film The Battle of Algiers was entered into evidence and shown to the jury in its entirety after a prosecution witness testified that a leader of the alleged conspiracy ordered other members to emulate the methods of terror depicted in the film. See M. KEMPTON, The Briar Patch 162, 199, 213, $271-72$ (1973); P. Zmiroth, Perversions of Justice 159-60 (1974). In the trial of Angela Davis for alleged participation in planning a courthouse escape, the prosecution introduced rolumes, said to belong to Davis, that contained academic studies of violence. A. Davis, AN Autoblography 359 (1974); see also Barker, Evidence: Did Angela Davis Testify?, 37 ALbaNy L. REv, 1, 20 (1972). The defendants in both cases were acquitted by the jury. Further, in a prosecution for conspiracy to bomb the statue of Liberty and commit other crimes, the Government introduced evidence indicating that defendants were connected with the Black Liberation Front and Canadian separatist groups and that one defendant had traveled to $\mathrm{Cuba}$ where he was associated with Che Guevara. United States v. Bowe, 360 F.2d 1, 14 (2d Cir.), cerl. denied, 385 U.S. 961 (1966).

5. Evidence of a defendant's political speech is often admitted into evidence to prove offenses that themselves punish speech of a particular content, such as sedition or incitement to violence. The focus of this article, however, is not on these prosecutions, in which the chief issue is the constitutionality of punishing particular speech itself, but rather on the permissibility of introducing evidence of protected speech in the course of proving a nonspeech offense of undoubted constitutional validity.

6. The Rosenbergs were charged with conspiracy to violate $\S 2$ (a) of the Espionage Act of 1917, then codified as 50 U.S.C. $\$ 32$ (a) (1946), which provided:

Whoever, with intent or reason to belicve that it is to be used to the injury of the United States or to the advantage of a foreign nation, communicates, delivers, or transmits, or attempts to, or aids or induces another to, communicate, deliver, or 
The Government contended that Julius Rosenberg, as the key figure in a Soviet espionage ring, had secured highly secret information, including sketches of the atomic bomb, and then transmitted that information to the Soviet Union. All three defendants were found guilty, and the Rosenbergs were sentenced to death. After a vigorous legal struggle ${ }^{7}$ and the rejection of petitions for executive clemency, the Rosenbergs were executed on June 19, 1953. Sobell was sentenced to thirty years in prison and remained incarcerated until January, 1969.

\section{A. Possible Uses of Evidence in Rosenberg}

From the initial stages of the Rosenbergs' trial-the questioning of prospective jurors on voir dire and the Government's opening statement-it was clear that the prosecution intended to introduce substantial evidence bearing on the political views and Communist Party membership and activities of Julius and Ethel Rosenberg. ${ }^{8}$ This strategy was bitterly opposed from the outset by defense counsel, ultimately without success. As introduced, the disputed evidence took two forms: (I) evidence that Julius and Ethel Rosenberg held certain political views-specifically, that they preferred the Soviet form of government to the form of government of the United States; ${ }^{9}$ and

transmit, to any foreign government . . or to any representative, officer, agent, employee, subject, or citizen thereof, either directly or indirectly, any document, writing, code book, signal book, sketch, photograph, photographic negative, blue print, plan, map, model, note, instrument, appliance, or information relating to the national defense, shall be punished by imprisonment for not more than twenty years: Provided, That whoever shall violate the provisions of this subsection in time of war shall be punished by death or by imprisonment for not more than thirty years ....

The section, as further amended, is now codified as 18 U.S.C. $\$ 794$ (a) (1970). The related conspiracy provision is $i d . \$ 794$ (c).

7. See note 2 supra.

8. In his opening statement the prosecutor declared, "[t]he evidence will show that the loyalty and the allegiance of the Rosenbergs and Sobell were not to our country, but that it was to Communism, Communism in this country and Communism throughout the world." Exhibit to Petition for Certiorari at 180, Rosenberg v. United States, 344 U.S. 838 (1952) (reproducing transcript of trial in Southern District of New York) [hereinafter cited without cross-reference as Transcript]. The prosecutor further stated that Sobcll and Julius Rosenberg "dedicated themselves to the cause of Communism," id. at 181 , and that "love of Communism and the Soviet Union" led them into espionage, id. at 182. For voir dire questioning of prospective jurors that suggested the relevance of Communist party membership and affiliation to issues of the case, sce $i d$. at 62-79, 93; see also id. at 119-20.

9. Id. at 414-21, 789.91. See note 41 infra. On cross-examination Julius Rosenberg further acknowledged that during World War II he believed that the Soriet Union was making "the major" contribution to the war effort, even after the opening of the second front, Transcript at 1174. He also acknowledged his belief that the Soviets had made advances in their way of life, id. at 1079, 1173, 1237-39. 
(2) evidence that Julius and Ethel Rosenberg had entered into certain political associations-specifically, that they were members of the Communist Party of the United States and were affiliated with organizations said to be related to the Communist Party.10 Further, the Government introduced testimony of Elizabeth Bentley, a former Communist Party member and an "expert" on Party affairs, for the purpose of "connecting" Party membership with possible espionage on behalf of the Soviet Union.11

Under what theory was this evidence admitted? Possession of the political views and associations attributed to the defendants did not in itself constitute a crime-at least not the crime for which the Rosenbergs were being tried. Nor did possession of such views or associations constitute a distinct element of the offense with which the defendants had been charged-conspiracy to commit espionage.

Evidence may be admissible, however, if it is relevant to an element of the offense, that is, if it makes the existence of that element more or less probable than it would have been without the evidence. ${ }^{12}$ The question of whether the evidence is relevant is thus the first to be asked in considering its admissibility. Assuming that the evidence is relevant, and not excluded under a categorical doctrine such as the hearsay rule, the second question is whether the evidence should be excluded because it is unduly prejudicial, misleading, or time-consuming. This second determination requires a balancing of the probative value of the evidence against the risk of

10. Evidence was introduced to the effect that Julius Rosenberg was dismissed from government employment because of membership in the Communist Party, Transcript at 241-42, 1182-86, 1303; that the Rosenbergs had actively pursued Communist Party activities, id. at 679; see also id. at 423-24; that at one time the Rosenbergs were in the habit of buying the Daily Worker, id. at 424, 679; see also id. at 1237, 1239-40; that Julius Rosenberg had contributed to and had collected money for the Joint Anti-Fascist Refugee Committee, id. at 1176-78; and that Ethel Rosenberg had signed a petition for a Communist Party candidate for city council, id. at 1346-47, 1352; see also id. at 1350 . Julius Rosenberg was also questioned about his connection with the International Workers Order, which, the prosecutor suggested, was "a Communist organization." $Y d$. at 1178-81. The Rosenbergs invoked their privilege against compulsory self-incrimination when asked about membership in the Comnunist Party. Id. at 1183, 1186, 1277; see also id. at $1309,1358,1371$.

Further, Max Elitcher, a callege classmate of Sobell and Julius Rosenberg, testified that Sobell had recruited him into the Communist Party, id. at 203-05, 224; that Sobell had acted as chairman of a Communist Party group in Washington, D.C., id. at 225; that the group discussed Marxist-Leninist theory and current events reported in the Daily Worker, id. at 226; that the chairman of the group instructed members to infiltrate other organizations, $i d$; and that "we were to go out and to gain support from people around us for the position of the Soviet Union," id. at 229.

11. For a discussion of this evidence, see pp. 1637-38 infra.

12. See, e.g., James, Revelancy, Probability and the Law, 29 C.sLif. L. Rev. 689, 704 (194I). 
prejudice or other danger posed by its admission. The traditional view of this balancing process strongly favors the admissibility of evidence, and in some formulations requires that the prejudicial danger of evidence must "substantially outweigh" its probative value before it may be excluded. ${ }^{13}$ Moreover, the accepted view confides broad discretion to the trial judge in the process of balancing and contemplates that appellate review will be sparingly exercised. ${ }^{14}$

Since a determination of logical relevance is the essential first step in evidentiary analysis, it is a matter of substantial importance that in the Rosenberg case the relevance of the defendants' political views and associations does not emerge with uniform clarity from the language either of the trial or of the appellate court. It is not always clear, either in the transcript of the trial or in the opinion of the appellate court, precisely to which element of the offense the evidence was thought to be relevant. Further, the trial and appellate courts do not appear to be in complete agreement with respect to the nature of the logical relevance of the defendants' political activity.

At the outset of the trial, Judge Kaufman indicated that evidence of the defendants' political associations would be admissible to show the defendants' "motive," apparently in order to give rise to a possible inference that the defendants performed acts of espionage. ${ }^{15}$ He then shifted, however, from this rationale to assertions that evidence of political views and associations was admissible to show the defendants' intent to give advantage to a foreign nation-a distinct element of the offense with which the Rosenbergs were charged. ${ }^{16}$

13. E.g., Lniform Rule of Evidence 45 (1953 version); Fed. R. Evid. 403; CaL. Evid. Code $\$ 352$ (West 1966). Cf. Model CoDe of Evidexce Rule 303 (permitting exclusion of evidence in discretion of trial judge "if he finds that its probative value is outweighed [rather than "substantially" outweighed] by the risk that its admission will . . . create substantial danger of undue prejudice"). Even under such a rule the burden is placed on the party sceking the exclusion of evidence. See generally Dolan, Rule f03: The Prejudice Rule in Evidence, 49 S. CaL. L. Rev. 220 (1976).

14. See Dolan, supra note 13 , at $225,227$.

For analyses of the evidence of the Rosenbergs' political views and activities under the balancing test, see Columbia Note, supra note 3, at 223-28, and Pitofsky, supra note 3, at $613-14$.

15. Responding to an objection to a passage in the prosecutor's opening statement, Judge Kaufman remarked that if the Gorernment sought to show that an interest in Communism established a "motive for what they [defendants] were doing," he would rule on the issue later. Transcript at 181 . Judge Kaufman subscquently accepted testimony on Sobcll's Communist Party affiliation, subject to "causal connection . . . purely on the question of molive and not as proving the charge." Id. at 200 (emphasis added). In the course of the discussion on this point, Judge Kaufman remarked that "I must accept the good faith of the prosecutor that he will show a causal connection between Communism and the commission of the acts charged in the indictment." Id. at 199 (emphasis added). See id. at 200, 201, 202, 215. See also id. at 216-17.

16. See note 30 infra. 
Moreover, while Judge Kaufman ultimately abandoned references to "motive" in his instructions to the jury, Judge Frank, writing for the court of appeals, asserted that evidence of political statements may show a "motive for . . . spying" or an "intent to do so," and that Communist Party membership may bear on "motive or intent to aid Russia."17 Judge Frank's opinion thus not only suggests important deviations from Judge Kaufman's ultimate view at trial, but also introduces substantial ambiguities and confusions of its own.

The ambiguous and apparently conflicting statements of the trial and appellate courts suggest several possible uses of the evidence in question. To aid analysis of the views of each court, it will be useful to separate the various distinct uses of evidence that may be concealed in references to "motive" and "intent" and to consider the ways in which the disputed evidence may have been relevant to the offense with which the Rosenbergs were charged.

1. Use of speech or association to show that defendants committed the acts charged. Evidence is relevant if it increases or decreases the probability that the criminal acts charged were committed by the defendants. In United States $v$. Rosenberg, evidence of the defendants' political views and associations may have been used in either or both of two ways to show that the defendants committed the acts charged: ${ }^{18}$ the evidence may have shown (a) motive for committing the acts or (b) intention to commit the acts.

a. Motive for committing an act. A jury may believe it more likely that an individual performed a certain act if it is shown that he had a "motive" for performing the act. A motive is a general desire or other emotion that may lead to the performance of an act. ${ }^{19}$ Motive may be proved, of course, by an explicit statement by the defendant that he or she possesses the motive in question. Since such

17. United States v. Rosenberg, 195 F.2d 583, 595, 596 (2d Cir.), cert. denied, 344 U.S. 838 (1952).

18. In Rosenberg the acts charged included the act of entering into the conspiratorial agreement to commit espionage and the specific acts of espionage (e.g., receiving and transmitting plans of the atomic bomb) performed pursuant to that agreement. Much of the Government's evidence against the Rosenbergs was intended to prove the commission of acts such as the solicitation and receipt of defense information, from which the existence of the agrecment could be inferred.

19. See 1 J. Wigmore, Evidence \$ 117 (3d ed. 1940).

Notice the distinction between motive for committing an act and intention to commit that act. Motive for performing an act is a more general desire (or other emotion) that may be gratified by the performance of the act, but may conceivably be gratified in some other way as well. Intention to perform an act, discussed below, is a more focused and specific desire or plan to perform the very act in question. Thus, a general dcsire for money may be a motive for robbing a store, but such a general state of mind is quite different from an actual intention to rob the store. See generally Conk, Act, Intention, and Motive in the Criminal Law, 26 YALE L.J. 645, 658-62 (1917). 
explicit statements are rarely available, however, motive is more frequently shown by circumstantial evidence. ${ }^{20}$ The circumstantial evidence gives rise to an inference of motive-a state of mind-from which one can draw the further inference that the person performed the act for which he had the motive. ${ }^{21}$ Thus it may be asserted that evidence of the Rosenbergs' membership in the Communist Party or of their favorable statements about the form of government of the Soviet Union might give rise to an inference that they possessed a general desire to further the goals of the Soviet Union. Possession of such a motive, it could be argued, may have increased the probability that the Rosenbergs either committed acts of espionage on behalf of the Soviet Union or entered into a conspiracy to do so.

b. Intention to commit an act. Evidence that an individual possessed the intention to perform a specific act is relevant for the purpose of showing that he subsequently acted in accordance with that intention and proceeded to perform the act. ${ }^{22}$ As in the case of motive, evidence showing an individual's intention to perform an act is not restricted to his statement of intention, but may also include evidence of other statements or acts from which an inference of such intention can be drawn. It might be argued, for instance, that Communist Party membership or statements favoring the Soviet form of government gave rise to an inference that the defendants intended to perform acts of espionage, from which it might then be inferred that defendants did in fact commit those acts or conspire to do so. ${ }^{23}$

2. Assuming an act has been proved, use of speech or association to show the intent of the defendant in performing the act. Evidence is also relevant if it tends to show that a person possessed a certain state

20. For example, evidence of defendant's large gambling losses might be introduced to show the defendant's need and hence his desire for money-a possible motive for the defendant's alleged robbery of a store.

21. The "external fact" giving rise to an inference of motive-e.g., the gambling losses-is sometimes itself referred to as the "motive," an improper usage that "tends to obscure the double evidential step involved." $1 \mathrm{~J}$. Wigmore, supra note 19 , at $\$ 117$. In assessing the probative value of the evidence, it is important to realize that at least two inferences are involved, since either may have vitiating weakness.

22. See, e.g., Mutual Life Ins. Co. v. Hillmon, 145 U.S. 285, 299-300 (1892).

23. Any inference from motive to an act requires an intermediate inference from motive to the actor's intention to perform the act. Evidence used to show motive often can be used to show the actor's intention to perform the act as well. Thus with respect to evidence of the Rosenbergs' political views, the use of evidence to show intention does not seem to differ significantly from the use of evidence to show motive. Rather, the two analyses appear to be essentially equivalent techniques for explaining the ultimate inference from speech to action. In the case of Communist Party membership, however, it might be argued that "expert" testimony concerning Party discipline, see p. 1637 infra, might be employed more directly to establish intention to commit espionage, from which the less remote inference from intention to action might conceivably be drawn. 
of mind, which itself constitutes a specific element of the offense. Used in this sense, a finding of intent is not used to give rise to a further inference of action, but is itself the thing to be proved..$^{24}$

a. Intent to perform an act. In order to prove many criminal offenses it is necessary to show both that the defendant performed a specific act and that the defendant intended to perform that act. In the Rosenberg case, however, if the defendants did solicit and receive atomic energy information, as the Government charged, there was no possibility that such acts were performed accidentally or unknowingly. Thus even if the Rosenbergs had been prosecuted for the substantive offense of espionage, the question of "intent" in this sense would not have been the subject of specific proof at trial.

b. Intent in conspiracy prosecutions. The Rosenbergs, however, were not prosecuted for espionage, but rather for conspiracy to commit espionage, and the offense of conspiracy has its own unique requirements of intent. In a conspiracy prosecution the government must show an intent to conspire, which ordinarily possesses two separate aspects: the conspirator must (i) intend to act in concert with other conspirators and (ii) intend, in so acting, to accomplish a specific end forbidden by statute. ${ }^{25}$ Thus, in Rosenberg, each defendant must be shown to have intended (i) to act in concert with others (ii) for the purpose of transferring national defense information to the Soviet Union. Both aspects of the requisite intent would be shown by proving the conspiratorial acts attributed to the defendants by witnesses for the prosecution: soliciting and receiving defense information for the express purpose of transmitting it to the Soviet Union. ${ }^{26}$ Thus if the jury decided that the defendants performed the

24. In considering this type of evidence of intent, it is useful to assume that performance of the act in question has been proved. The discussion can then focus on the state of mind of the actor in performing the act.

25. See generally Harno, Intent in Criminal Conspiracy, 89 U. PA. L. REv. 624 (1941). In many jurisdictions a criminal conspiracy may be established even if the specific end sought to be achieved by the conspirators is not independently proscribed by statute. For a history of conspiracy doctrine focusing on this problem, see Sayre, Criminal Conspiracy, 35 Harv. L. Rev. 393 (1922).

26. According to David and Ruth Greenglass, the brother and sister-in-law of Ethel Rosenberg and the chief Government witnesses at trial, Julius Rosenberg sought information relating to the atomic bomb so that it could be given "to the Russians." Transcript at 424. The Greenglasses testified that Julius and Ethel made extensive arrangements with them for the procurement of atom bomb information to be transmitted to the Soviet Union. Id. at 421-29, 438-54, 489-500, 510-13, 679-705. Julius was said to have introduced David Greenglass to someone whom Julius identified as a "Russian," who asked David, a machinist at the Los Alamos nuclear laboratory, for military information. Id. at 451-54. See also, e.g., id. at 692, 708, 786 (payments from "the Russians"); id. at 710 (plans for escape to Soviet Union). 
acts alleged by the prosecution, intent in this sense would not have constituted a separate issue with respect to the Rosenbergs. ${ }^{27}$

c. Intent (or reason to believe) that the information is to be used to the advantage of a foreign nation. To establish an offense under $\$ 2$ (a) of the Espionage Act of 1917, it is not sufficient to show that the defendant transmitted national defense information to a foreign government and that he intended that the information be so transmitted. The government must also prove, as a distinct element of the offense, that the defendant acted "with intent or reason to believe that [the information] is to be used ... to the advantage of [that] foreign nation." ${ }^{28}$ Similarly, in a prosecution for conspiracy to violate $\S 2(a)$, the government must show that, in conspiring, the defendants intended or had "reason to believe" that such transfer of information would give advantage to the foreign nation. In the Rosenberg case, then, evidence that the defendants' political views and associations indicated benevolence toward the Soviet Union may have been used to show that the defendants-assuming they did agree to transfer information to the Soviet Union-did so with the intent to give advantage to the Soviet Union.

\section{B. Judicial Uses of Evidence in Rosenberg}

With these distinctions in mind, it will be useful to examine the treatment of evidence of political views and associations by the trial judge and by the court of appeals. Notwithstanding the widespread assumption that Judge Kaufman admitted evidence of the defendants' political views and associations to show "motive" (to give rise in turn to an inference that the defendants committed the acts charged), ${ }^{29}$ Judge Kaufman's instructions to the jury make clear that he was not

27. A significant question of conspiratorial intent, however, did arise with respect to Sobell, who argued that the evidence against him indicated, at most, that he intended to participate with Julius Rosenberg in a conspiracy to transfer information unrelated to atomic energy and that this alleged conspiracy was distinct from the more comprehensive atomic bomb conspiracy charged in the indictment. Although Sobell's contention was rejected on appeal, Judge Frank, dissenting on this point, argued that the question of Sobell's intent to participate in the larger conspiracy should have been submitted to the jury. United States v. Rosenberg, 195 F.2d 583, 600-02 (2d Cir.), cert. denied, 344 U.S. 838 (1952).

28. 18 U.S.C. $\$ 794$ (a) (1970). See note 6 supra. This requirement, in the wider context of current espionage statutes, is exhaustively analyzed in Edgar \& Schmidt, The Espionage Statutes and Publication of Defense Information, 73 Colum. L. Rev. 929 (1973). Section 794(a) is also violated if the defendant acts with "intent or reason to believe that [the information] is to be used to the injury of the United States," but statutory intent of this nature was not charged in the Rosenberg indictment.

29. See, e.g., Columbia Note, supra note 3, at 227-28. See also S. Fixeberg, supra note 3, at 60-61; Pitofsky, supra note 3, at 613-14. 
sending the evidence of Communist Party association to the jury for this purpose. Rather, he instructed the jury to consider evidence of Party membership and activity only on the question of the defendants' intent or reason to believe that the information allegedly transmitted would be used to the advantage of the Soviet Union, a distinct element of the offense with which they were charged.30

Yet it seems clear that, in the full context of the case, the disputed evidence had little, if any, real value for this purpose. If the jury accepted the Government's contention that the Rosenbergs, amid elaborate precautions against detection, ${ }^{31}$ had solicited and received information about the atomic bomb for the express purpose of transmitting that information to the Soviet Union, ${ }^{32}$ the inference that the defendants intended to give advantage to the Soviet Union would seem to arise without question from their performance of the acts themselves. ${ }^{33}$ Further, the conclusion that the Rosenbergs had "reason to believe" that secret information about the atomic bomb would give advantage to the Soviet Union would seem to arise with, if anything, even greater clarity. Thus on the question of intent to give

\section{In his instructions to the jury, Judge Kaufman stated:}

Now I wish to instruct you at this point that $I$ have admitted testimony as to membership or activity in the Communist Party and also testimony to the effect that the Communist Party is dedicated to furthering the interests of the Union of Soviet Socialist Republics solely on the question of the defendants intent or reason to believe that the alleged secret information to be transmitled would be used to the advantage of a foreign nation, in this case the Union of Sovict Socialist Republics, which is an element of the charge that the Government must prove beyond a reasonable doubt.

I wish to caution you most strenuously that proof of Communist Party membership or activity does not prove the offense charged in this indictment, but may be considered by you solely on the question of intent which is one element of the crime charged here.

Transcript at 1558 (emphasis added).

Judge Kaufman's remarks in the later stages of the trial generally accord with his instructions to the jury. For example, testimony that the Rosenbergs considered the form of government of the Soviet Union "the ideal form of government" was admitted by the court on the ground that "[o]ne of the issues in this case is whether or not they intended to give an advantage to Russia. On that issue I take the evidence." $I d$. at 789 . In admitting the testimony of Elizabeth Bentley describing the nature of the Communist Party, Judge Kaufman remarked: "I assume that this is the causal connection that we have been talking about between the membership in the party and intending to give an advantage to a foreign government, to wit, the USSR, as charged in the indictment." Id. at 965 (emphasis added). For a somewhat more ambiguous passage, however, see id. at 1022. Although ignored by some commentators, see note 29 supra, the effect of Judge Kaufman's instructions was clearly noted by the parties. See, e.g., Petition for Certiorari at 10, 40 n.14; Brief for the United States in Opposition at 34-35, Rosenberg v. United States, 344 U.S. 838 (1952).

31. See, e.g., Transcript at 446-47, $689-90$ (use of torn jello box as recognition devicc).

32. See note 26 supra.

33. See Petition for Certiorari at 45, Rosenberg v. United States, 344 U.S. 838 (1952). In addition, there was testimony that Julius Rosenberg specifically requested information that "could be of any value, of any assistance to the Soviet Union." Transcript at 238. 
advantage to the Soviet Union, the incremental probative value of evidence of Communist Party membership and favorable views concerning the Soviet Union seems little better than nonexistent. ${ }^{34}$ And whatever minimal probative value the evidence may have had seems clearly insufficient to bear the weight of the severe prejudice arising from abundant evidence of Communist Party membership and activities. $^{35}$

While the trial court instructed the jury to use the disputed evidence solely for the purpose of showing the defendants' intent to give advantage to the Soviet Union, it appears that the court of ap-

34. Under traditional doctrine it is the incremental probative value of evidence that is to be weighed against the danger of prejudice-that is, the probative value added by the evidence in question to that afforded by nonprejudicial evidence otherwise present in the case. See Dolan, supra note 13, at 250-52; Trautman, Logical or Legal RelevancyA Conflict in Theory, 5 VAND L. Rev. 385, $397 \&$ n.48 (1952). In a related area, courts have excluded evidence of other crimes offered to show defendant's criminal intent where the only disputed question was whether defendant had performed certain acts and where there was little question that, if the acts had been performed by defendant, the requisite intent was present. State v. Gilligan, 92 Conn. 526, 103 A. 649 (1918). See Note, Other Crimes Evidence at Trial: Of Balancing and Other Matters, 70 YALE L.J. 763, 770.71 (1961).

35. If the defendants had admitted transferring information, but had denied having the requisite statutory intent or reason to believe, it might have been more clearly necessary for the Government to introduce independent evidence on that element of the offense. No occasion arose for any such argument in Rosenberg, however, since the defendants denied that they had transmitted any material whatsoever or had entered into any conspiracy to do so. See Petition for Certiorari at 45, Rosenberg v. United States, 344 U.S. 838 (1952).

For similar reasons, cases such as Haupt v. United States, 330 U.S. 631 (1947), which was relied on by the prosecution at trial, Transcript at 414 , and cited by the court of appeals, United States v. Rosenberg, 195 F.2d 583, 595 (2d Cir.), cert. denied, 344 U.S. 838 (1952), seem clearly distinguishable. In Haupt, a treason prosecution, the defendant's son cntered the United States from a German submarine during World War II, for the purpose of committing sabotage. Allegedly knowing of his son's intentions, defendant gave him shelter in his house, helped him obtain employment in the bomb-sight factory in which the son had previously been employed, and assisted him in buying a car. In order to convict for treason, however, proof of overt acts giving aid and comfort to the enemy is not enough. Overt acts must be accompanied by an intent to "adhere" to the enemy; that is, the defendant in performing the acts must intend to direct his allegiance to the enemy and away from the United States. Cramer v. United States, 325 U.S. 1, 29 (1945). The defendant in Haupt argued that his acts were merely the acts of an "indulgent father," and that he did not possess the requisite intent for a conviction of treason. Haupt v. United States, 330 U.S. at 642. In order to show intent to adhere to the enemy-an intent which, according to the defendant, could not be inferred from the overt acts alone-the Court permitted introduction of defendant's statements "showing sympathy with Germany and with Hitler and hostility to the United States." Id. In Haupt, therefore, the value of the evidence of pro-German views was substantial (or at least more than minimal) on the question of defendant's intent to "adhere" to the enemy, since inferences on this score to be drawn from the overt acts were ambiguous and since the defendant specifically argued that no inference of such intent could in fact be drawn from the overt acts themselves. This case thus seems substantially different from Rosenberg, where the acts attributed to the Rosenbergs give rise, with absolutely no ambiguity, to the inference that the acts were performed with intent to give advantage to the Soviet Union or that defendants had reason to believe that their acts would do so. 
peals affirmed the conviction at least in part on a different theory. Although Judge Frank's opinion is not entirely clear, it appears that he proceeded on the assumption that the disputed evidence was submitted to the jury to raise an inference that the defendants committed acts of espionage by showing that they had a motive for committing the acts-use 1(a) above. Judge Frank's opinion approved testimony that the Rosenbergs "expressed a preference for the Russian social and economic organization over ours," ${ }^{36}$ on the ground that

[a]n American's devotion to another country's welfare cannot of course constitute proof that he has spied for that other country. But the jurors may reasonably infer that he is more likely to spy for it than other Americans not similarly devoted. Hence this attitude bears on a possible motive for his spying, or on a possible intent to do so when there is other evidence in the case that he did such spying. ${ }^{37}$

Admission of evidence that the defendants were members of the Communist Party was apparently approved, at least in part, on the same theory:

The government had to prove that the Communist Party was tied to Soviet causes in order to make membership in it meaningful as evidence of motive or intent to aid Russia. . . . To that end, the government put Elizabeth Bentley on the stand. She testified

36. United States v. Rosenberg, 195 F.2d 583, 595 (2d Cir.), cert. denied, 344 U.S. 838 (1952).

37. Id. (emphasis added). Judge Frank's reference to "a possible motive for . . . spying" is a clear reference to use $\mathrm{l}$ (a) above (proof of motive to show that acts of espionage were performed). The phrase "a possible intent to do so [spy] when there is other evidence in the case that he did such spying" is more problematic. Since this reference follows a general statement that "the jurors may reasonably infer that he is more likely to spy for [another country] than other Americans not similarly devoted" and is introduced by the word "hence," the phrase may indicate an instance of use l(b) above (proof of intention used to give rise to an inference of action). The reference to "other evidence in the case that he did such spying," although puzzling in this context, may refer back to Judge Frank's remark that evidence of "[a]n American's devotion to another country's welfare cannot . . . constitute proof"; that is, such evidence will not in itself suffice to prove the entire crime of espionage.

Alternatively, it is possible that the reference to "intent" may correspond to Judge Kaufman's use of the same or similar testimony for the purpose of showing intent to give advantage to the Soviet Union, use 2(c) above. Although such an interpretation might be thought to be supported by Judge Frank's citation of the Haupt case, the words "intent to do so" (i.e., intent to spy) might not bear the weight of this interpretation, particularly in light of Judge Frank's later use of the more apposite, but still ambiguous, phrase "intent to aid Russia." See p. 1635 infra. However, since any inference from the disputed political statements to the performance of acts of espionage must proceed through an intermediate inference of a state of mind much like intent to give advantage to the Soviet Union, it would seem that a use of the evidence to show action may well include its use to show the statutory intent. 
that the American Communist Party was part of, and subject to, the Communist International; that the Party received orders from Russia to propagandize, spy, and sabotage; and that Party members were bound to go along with those orders under threat of expulsion. If the jury believed her, she supplied the missing link connecting the Communist Party with the Soviet Union, and making Communist Party membership probative of motive or intent to aid Russia. ${ }^{38}$

Since Judge Frank appears to put forth a ground of relevance not relied upon by the trial court in its instructions, the opinion of the court of appeals raises the initial question of whether the admission of arguably prejudicial evidence may be affirmed on the basis of a finding of relevance other than that ultimately relied upon by the trial judge. A number of decisions suggest, at least, that such an affirmance is impermissible. ${ }^{39}$ Furthermore, the court of appeals may well have overestimated the probative value of this evidence through its failure to analyze carefully the strength of the evidence for the use for which it was approved. Indeed, Judge Frank's opinion ignored difficult problems in the admission of both classes of the disputed evidence.

In considering the admissibility of statements expressing "a preference for the Russian social and economic organization over ours," the court of appeals argued that one could infer that an American "[devoted] to another country's welfare . . . is more likely to spy for it than other Americans not similarly devoted." $¥ 0$ Implicit in this argument is the apparently unconscious conflation of two distinct

38. 195 F.2d at 595-96 (emphasis added).

39. E.g., Shepard v. United States, 290 U.S. 96, 103 (1933); Pcople v. Zackowitz, 254 N.Y. 192, 200, 172 N.E. 466, 469 (1930); State v. Goebel, 36 Wash. 2d 367, 378, 218 P.2d $300,306(1950)$. If an appellate court affirms on a theory of relevance other than the theory asserted by the trial court, the action of the appellate court seems clearly incorrect. First, the defendant in such a case is deprived of an initial balancing of the probative value of the evidence for the use newly asserted by the appellate court against the prejudicial dangers posed, a balancing confided to the trial judge in the first instance. Second, the trial judge may actually have decided $s u b$ silentio that the evidence was inadmissible for the purpose asserted by the appellate court.

The latter course seems to have been taken in Rosenberg, since the trial judge excluded all other uses of the evidence by instructing the jury that the evidence was admissible solely for the purpose of showing intent to give advantage to the Sovict Union. In so doing, Judge Kaufman would seem to have intentionally rejected the use of the evidence to show "motive"-use 1(a) above-the use ultimately accepted by the court of appeals. Indeed, Judge Kaufman seems to have entertained precisely that use at an early point in the trial only to exclude it later. Furthermore, the fact that an appellate court reaches out for a new basis of relevance suggests a finding by it that the basis asserted by the trial court was improper or insufficient as a matter of law. Grounds for such a finding with respect to the basis of relevance asserted in Judge Kaufman's instructions are suggested in the discussion at pp. 1632-33 supra.

40. United States v. Rosenberg, 195 F.2d 583, 595 (2d Cir.), cert. denied, 344 U.S. 838 (1952). 
propositions. The proposition (1) that defendants "expressed a preference for the Russian social and economic organization over ours" is viewed by Judge Frank as equivalent to the proposition (2) that defendants are "[devoted] to another country's welfare." That (1) presupposes (2) may have been widely held as a tenet of Cold War doctrine, but the two propositions are not equivalent statements. Clearly, a person can have a preference for a type of "organization" without preferring the nation in which that type of organization is found.11 There may be countervailing factors unrelated to social and economic organization that militate against any such preference. Moreover, even if a "preference" for the foreign nation can be inferred from a preference for its social and economic organization, a further logical step is required to transform that "preference," a rather detached judgment, into the type of strong attachment suggested by the word "devotion." $\$ 2$ This transformation is also concealed in Judge Frank's opinion.

The use of this evidence in the manner suggested by the court of appeals illustrates the serious problems inherent in using abstract statements concerning political forms for the purpose of giving rise to inferences of illegal action by the speaker. The very inferences unconsciously drawn by Judge Frank-inferences of devotion to a suspect foreign nation drawn from general remarks apparently favorable to that nation-are precisely those unconscious inferences that mark periods of political excitement or hysteria. ${ }^{43}$ In treating the evidence in this manner, Judge Frank ignored rather than analyzed the serious problems of questionable probative value posed by the use of this evidence.

Judge Frank's opinion similarly glosses over difficult analytical problems in the use of evidence of the Rosenbergs' membership in the Communist Party. The central problem arises from the fact that

41. In the actual testimony, the phrase "form of government" was prominent. Thus, according to one witness, the Rosenbergs "were comparing our form of Government to the form in Russia, and ... they said ... Russia was the ideal form of government, the Russian form of government." Transcript at 789. See id. at 790. Although testimony implied that the Rosenbergs" approval of the "Russian form of government" was enthusiastic, $i d$. at 789-91, defendants seem basically accurate in their argument, before the Second Circuit, that "there is nothing in the record to justify the description of approval of particular policies of another country, which was actually testified to, as preference of that country ...." Reply Brief for Appellant Sobell at 11, United States v. Rosenberg, 195 F.2d 583 (2d Cir.), cert, denied, 344 U.S. 838 (1952).

42. Thus, the defendants argued that "[n]othing in the proof indicates . . that this 'preference' had hardened into a devotion to a foreign government or country . . . ." Petition for Certiorari at 40 , Rosenberg v. United States, 344 U.S. 838 (1952).

43. If such inferences are unconsciously drawn by judges, there is at least an equal danger that they will be drawn by juries. See pp. 1643-44 infra. 
an inference must be drawn from the defendants' membership in a specific, named organization about which jurors have no firsthand knowledge. Such an inference is substantially different from those ordinarily drawn by jurors from the generalized material of their own experience. ${ }^{44}$ Certainly newspapers, books, and other out-ofcourt sources that describe the supposed qualities of a specific group should not suffice to permit a jury to draw inferences from membership in that group. ${ }^{45} \mathrm{In}$ an attempt to meet this problem and to provide evidence at trial of the character of the Communist Partyfrom which a further inference of the defendants' individual state of mind and actions might then be drawn-the Government called Elizabeth Bentley, an "expert" on the affairs of the Communist Party of the United States. ${ }^{46}$ Testifying that she had taken part in espionage, Bentley asserted that control was exercised by the Soviet Union over the activities of the American Communist Party ${ }^{47}$ and that the Party "only served the interests of Moscow." 48 If members refused to carry out the wishes of the Soviet Union, they would be expelled from the Party. ${ }^{43}$

Regarding Bentley's testimony, it should be noted, first, that the jurors were asked to use this expert testimony to reach a conclusion not based upon clear or determinate principles. Bentley's testimony did not pertain, for example, to the scientific underpinnings of a medical malpractice suit or to the working of machinery. Rather, her testimony was one person's (perhaps self-serving) theory about what is

44. Ordinarily, inferences are based on propositions drawn from the general experience of jurors. James, supra note 12, at $696 \mathrm{n} .15$. The nature of a specific group and the relations between that group and its members, however, are not matters of general experience. Indeed, any person who had firsthand experience with the specific group in question would have been excused from the jury.

45. Use of such sources for the purpose of imputing attributes to a specific group should be no more permissible than the use of such out-of-court sources to determine the nature of an individual defendant in the course of a trial. Accordingly, decisions under the Smith Act indicate that nothing like judicial notice of the attributes of the Communist Party may be used against a defendant in a criminal trial. Rather, the Party's relevant attributes must be established at trial in each case. Noto v. United States, 367 U.S. 290, 299 (1961).

46. Elizabeth Bentley, the "Red Spy Queen" of contemporary newspaper accounts was a former member of the Communist Party who had testified at two earlier trials and at a number of congressional hearings. For a critical analysis of her career as a witness particularly before congressional investigating committees, see H. PACkER, Ex-ComMUnist Witnesses 52-120 (1962). See also Bentley's autobiographical account, E. Bevtrey, Out of BONDAGE (1951).

47. Specifically, Bentley testified that the Soviet Union exercised control over Earl Browder, a leader of the Party during the period involved in her testimony. Transcript at 978 .

48. Id. at 978 .

49. Id. at 978-79. 
likely to have been a highly complex phenomenon, the structure and nature of the Communist Party of the United States during a particular period. Second, it should be noted that there is no clear indication that Bentley was at all familiar with the Communist Party circles of which the defendants were said to have been members. Accordingly, even if one accepts Bentley's testimony concerning the workings of organizational discipline on Party members of her acquaintance, there was no clear testimony about the discipline exerted on the Rosenbergs, on Sobell, or on the subgroups of the Party with which the Rosenbergs and Sobell may have been involved.

In general, inferring an individual's actions or state of mind from membership in an organization involves a double process of inference with double uncertainties. First, an inference must be drawn about the tenets of the organization from party documents or from statements of individuals other than the defendants. Such an inference often raises difficult problems: how does one know that the views of a particular officer or member of the organization represent the "views" of the organization as a whole? ? $^{30}$ If this problem is overcome an even more serious difficulty remains. If the defendant belongs to an organization that possesses many political views and goals, how strong is the inference that he, as an individual, shared the particular tenets of the organization that are in question?51 Again, Judge Frank's opinion glosses over these substantial problems without analysis. As a result, he ignored several difficult steps in the chain of inference originating with evidence of the Rosenbergs' membership in the Communist Party and thereby failed to explore important weaknesses in the probative value of that evidence.52

50. See, e.g., Noto v. United States, 367 U.S. 290, 298 (1961) (prosecution under membership clause of Smith Act in which the Court, in assessing evidence that Communist Party advocated violent overthrow of government, required sufficient (direct or circumstantial) evidence "to justify the inference that such a call to violence may fairly be imputed to the Party as a whole, and not merely to some narrow segment of it); Scythes v. Webb, 307 F.2d 905 (7th Cir. 1962) (judicial refusal to attribute views of leader of Socialist Workers Party to Party in general).

51. The defendants in Rosenberg thus argued that the Government had not shown "that the Rosenbergs personally accepted the alleged tenets of the Communist Party relevant here, or even knew of them." Petition for Certiorari at 42, Rosenberg v. United States, 344 U.S. 838 (1952).

52. Although the probative value of Communist Party membership in the form presented seems weak, there was a serious risk that the jury might draw a strong inference of the defendants' propensity to commit espionage from their Communist Party membership. Such an inference would be based not upon the tenuous evidence of Elizabeth Bentley introduced at trial, but rather upon the jurors' own assessment of the traits of Communist Party members and their propensity to commit espionage derived from out-of-court sources such as newspapers, magazines, and the other raw materials of popular opinion. The jury's use of out-of-court material for this purpose, however, would 
When Judge Frank moved to a consideration of the possible prejudicial impact of the disputed evidence, his treatment was characteristic of appellate review under the traditional standard. This standard confides to the trial judge the weighing of probative value and prejudicial danger and permits reversal on appeal only for an egregious error in striking the balance. ${ }^{53}$ Having established the logical relevance of the evidence, Judge Frank found that the trial court had not abused its discretion in admitting the evidence. He suggested, moreover, that if the defendants feared that the judge's limiting instructions would not be followed by the jury, they should have sought a trial by the judge alone. ${ }^{54}$

Although Judge Frank's opinion appears to assume that the appropriate assessment of prejudice had been undertaken by the trial court, Judge Kaufman did not clearly indicate that he viewed the risk of prejudice as a substantial factor to be weighed against the probative value of evidence of Communist Party association. ${ }^{55}$ Yet in the Rosenberg case, coming as it did in the heart of the Cold War period, evidence of the defendants' views and of their Communist Party affiliations unquestionably posed grave dangers of prejudice..$^{56}$

scem to be improper. See pp. 1636-37 \& notes $44-45$ supra. The possibility of this type of prejudicial use, in an extreme form, was acknowledged by the trial judge in Rosenberg when he cautioned the jury that "proof of Communist Party membership or activity does not prove the offense charged in this indictment ...." Transcript at 1558. The "offense charged in this indictment," of course, was conspiracy to commit espionage.

53. See p. 1627 supra.

54. $195 \mathrm{~F} .2 \mathrm{~d}$ at 596. It seems dubious practice, however, to foster techniques that unduly encourage a criminal defendant to waive the right to trial by jury. Further, under FED. R. CRIM. P. 23(a) the prosecution may ordinarily prevent the defendant from securing a trial by the judge alone. See Singer v. United States, 380 U.S. 24 (1965); Boudin, supra note 3, at 261-62. Among the other problematic aspects of Judge Frank's suggestion is the important fact that trial by jury affords the defendant a trier of fact from which prejudicial evidence may actually be withheld. The trial judge acting as trier of fact may or may not be able to perform the elaborate mental act of excluding inadmissible evidence from his mind; with a jury, however, the trier will ordinarily not hear the excluded evidence at all. For this reason as well, the possibility of securing a trial by judge alone secms inadequate as a substitute for the rigorous exclusion of unduly prejudicial evidence in a jury trial.

55. In a number of instances, for example, Judge Kaufman appeared content to admit the disputed evidence, once satisfied of its "connection" or logical relevance. See, e.g., Transcript at 1038-39; see also id. at 424.

56. Not long before the Rosenbergs' trial, the New York Court of Appeals remarked that "it is undeniable that for communism and its adherents and sympathizers, there has been widespread public aversion." Mencher v. Chesley, 297 N.Y. 94, 100, 75 N.E.2d 257, 259 (1947) (libel action). In the period in question, such "widespread aversion" continued to be prevalent, as reflected in such sources as congressional legislation, Internal Security Act of 1950, $\$ 2(1)$, (15), 50 U.S.C. $\$ 781(1)$, (15) (1970), judicial opinions, American Communications Ass'n v. Douds, 339 U.S. 382, $422-45$ (1950) (Jackson, J., concurring and dissenting), and public opinion polls, S. Stouffer, Communisir, Conformity, AND CiviL. Liberties 40.41 (1955).

Two members of the jury in the Rosenberg case have recently recalled holding similar 
Furthermore, even if some evidence of defendants' political views and Communist Party membership might properly have been admitted, it does not necessarily follow that the jury should have been permitted to hear the amount of evidence on this point that was actually introduced.57 Excessive repetition may emphasize the prejudicial aspect of the evidence without significantly increasing its probative value. In this light it is difficult to avoid the conclusion that more of the disputed evidence was introduced at trial than could have been justified by any legitimate purpose..$^{58}$

To summarize, even under the traditional test for admissibility, the decision in United States $v$. Rosenberg entailed serious problems. There was not only substantial ambiguity and even contradiction in the treatment of the evidentiary issues by the trial and appellate courts, but also a failure to undertake the careful analysis that may have exposed a serious overestimate of the probative value of the evidence. Certainly neither court confronted the difficult problems latent in the nature of the disputed evidence-problems that might have been more clearly perceived if deliberate analysis had been undertaken. As a result, the introduction of much of the disputed evidence seems to have been questionable even under the traditional test. Perhaps most importantly, however, underlying the somewhat cursory treatment by both courts was a failure to recognize that serious First Amendment issues were presented by this ostensibly routine dispute over the introduction of evidence.

\section{The Need for a First Amendment Prophylactic Rule}

Even under the traditional balancing test, there were serious problems in the disposition of the evidentiary issues in United States $v$.

views at the time of the trial. In a recent television interview, the jury foreman commented that "[d]uring my younger days, the idea of a Communist connoted something evil or dirty. It was a dirty word, actually." A. Goldstein, The Unouict Deith of Julius And ETHEL Rosenberg (unnumbered pages) (1975). Another member of the jury remarked:

[C]ommunism was . . . a bad thing. After all wed helped [them] in World War II, bailed them out, and here they are coming back at us . . . anyway they could. Taking over all those European nations and making slave states out of [them]; so . . . I Id.

think the feeling against communism was much more prevalent then than it is today.

57. See Pitofsky, supra note 3, at 613-14.

58. One commentator has remarked:

With respect to the Rosenbergs, there remains an uneasy feeling that by constant reference to ideological questions, the Government, at best, came perilously close to misdirecting the jury's attention away from legitimate issues; at worst, it took advantage of a limited exception for proof-of-motive to obtain a conviction based primarily on evidence of political heresy.

Id. at 614. See Boudin, supra note 3, at 258-59. But see Columbia Note, supra note 3, at 227-28 (approving introduction of evidence). 
Rosenberg. Whatever the result should have been under the traditional test, however, it is highly questionable whether that test, with its corollary of minimal appellate review, satisfies the imperatives of the First Amendment for assessing the admissibility of evidence of a criminal defendant's political speech or association. In such instances a more restrictive rule of exclusion should be applied.

The basic case for a more restrictive rule can be simply put. Whenever evidence of unpopular but protected speech or association is introduced against a criminal defendant, the jury may make improper use of that evidence by penalizing the exercise of First Amendment rights. In a criminal trial, the jury as a constituent of the court exercises the power of the state. Hence, the improper penalization of protected speech by a jury violates the First Amendment to the same extent as analogous action by any other governmental entity. It is particularly difficult, of course, to determine whether a jury has reached its decision on an improper basis. Courts must therefore take measures to lessen the risk that the jury may decide a case on such grounds. Although similar considerations underlie the traditional balancing of probative value against prejudicial danger, when the risk of prejudice involves a threat to First Amendment values the applicable test ought to be considered an aspect of First Amendment law, to be determined in accordance with First Amendment principles developed in other areas. Since it is established that procedural guarantees must be applied with special strictness when First Amendment rights are at stake, the admissibility of evidence of a defendant's protected speech or association should be determined by a test substantially more stringent than the balancing test ordinarily applicable in the case of evidence posing significant risks of prejudice.

\section{A. First Amendment Violations}

When the government introduces evidence of speech or association protected by the First Amendment to prove a nonspeech offense, it creates the danger that First Amendment interests will be impaired in one or more of three ways: first, the jury may convict the defendant, not because it is convinced that he is guilty of the offense charged, but to retaliate against him for his protected speech or association; second, the jury may draw an unduly strong inference from the defendant's speech or association to his guilt of the offense charged; and, third, the possibility of the foregoing two violations may exert a chilling effect on similar speech or association of others. 


\section{Retaliation Against Protected Speech or Association}

It is clear that the imposition of a disability by a governmental official in retaliation for protected speech or association violates the First Amendment even though the official purports to be acting under a rule that does not, by its terms, penalize that speech or association. Thus, if an applicant is denied a permit to conduct a parade, not for reasons of public order, but rather because the applicant is a Republican or because he has said "the mayor should not be reelected," the denial violates the First Amendment. Similarly, the discharge of a governmental employee supposedly for "insubordinate conduct" violates the First Amendment if the discharge is actually undertaken in retaliation for protected speech. ${ }^{59}$ Moreover, if an individual is prosecuted for a criminal offense because the prosecutor disapproves of his political activity, the prosecution violates the First Amendment even though the defendant may be guilty of the offense charged. ${ }^{60}$ In a criminal trial, of course, the jury exercises the power of the state. ${ }^{61}$ If under the guise of convicting a defendant of a criminal offense, a jury actually retaliates against him for speech that is protected under the First Amendment-punishing him for the speech, apart from any assessment of his guilt or innocence of the offense charged-the jury's action violates the First Amendment to the same extent as a penalty imposed for similar reasons by any other governmental officer. ${ }^{62}$

59. Perry v. Sindermann, 408 U.S. 593, 597 (1972). See also Elrod v. Burns, 427 U.S. 347, 355-60 (1976) (plurality opinion).

60. United States v. Falk, 479 F.2d 616, 623-24 (7th Cir. 1973) (en banc) (ordering evidentiary hearing to determine whether prosecution for failure to possess draft card was instituted in retaliation for defendant's activities as draft counselor); United States v. Steele, 461 F.2d 1148 (9th Cir. 1972) (reversing conviction for failing to answer census questions on ground that prosecution was undertaken in retaliation for defendant's participation in anti-census movement); United States v. Crowthers, 456 F.2d 1074 (4th Cir. 1972) (reversing convictions on ground that prosecution for demonstrations was undertaken in retaliation for content of defendants' speech). See Amsterdam, The OneSided Sword: Selective Prosecution in Federal Courts, 6 RuT.-CaM. L.J. 1 (1974).

61. See, e.g., J. Frank, Courts on Trial 132 (1949).

62. Of course the conviction by a jury for any patently improper reason-for example, because the defendant has red hair-can be viewed as a denial of due process. The defendant has been convicted of an act (or a condition) that is not a crime or that, at any rate, has not been included in the indictment or information on which he is being tried. See, e.g., De Jonge v. Oregon, 299 U.S. 353, 362 (1937) ("Conviction upon a charge not made would be shecr denial of duc process.") Courts ordinarily try to guard against this type of improper conviction through traditional evidentiary exclusionary rules, including the standard balancing test, and through the use of prophylactic jury instructions.

The thesis of this article is that, even though conviction on any improper basis may be thought to constitute a violation of due process, the dangers of improper conviction are so acute when evidence of protected speech is introduced against a criminal defendant, and the policies of the First Amendment so particularly strong, that prophylactic rules more stringent than the traditional balancing test must be applied. 
The Supreme Court has on a number of occasions acknowledged the likelihood of undetectable retaliation against protected speech by governmental officers and boards and has created First Amendment techniques for the purpose of guarding against such retaliation. ${ }^{63}$ As the Court has indicated, analogous retaliation by juries also seems likely. ${ }^{04}$

\section{Unduly Strong Inferences from Protected Speech or Association}

The risk of retaliation is not the only danger posed to First Amendment rights when evidence of protected speech or association is introduced against a criminal defendant. There is also the danger that the jury may draw a stronger inference than is warranted from the defendant's speech or association to his guilt of the offense charged, and thereby impose a burden on the exercise of First Amendment rights. ${ }^{65}$ Unduly strong inferences of guilt from protected speech or association may take a number of forms. For example, a jury might unreasonably infer that members of an unpopular political group, or persons holding unpopular political views, are evil persons and are therefore more likely than others to commit crimes in general. The unarticulated major premise supporting such an inference appears to have been widely held during the Cold War period with respect to members of the Communist Party, who were commonly

63. See notes $101 \& 103$ infra.

64. See pp. 1658-60 infra.

65. The likelihood that evidence will be scriously overvalued by a jury is one of the most persistent and widespread dangers imperiling the fairness of trials. In fact, fears of prejudice of this general type figure prominently in many of the most conspicuous aspects of the law of evidence. Thus, one of the reasons for placing strict limitations on the introduction of evidence of prior convictions of a criminal defendant is the fear that the jury may draw an unreasonably strong inference from defendant's prior crimes to his guilt of the crime for which he is presently being tried. Sec, e.g., R. Lempert \& S. Saltzburg, A Modern Approdch to Evidence 153 (1977); 1 J. Wigmore, supra note 19, $\$ 194$, at 650 . Similarly, hearsay is excluded principally because it may be overvalued by a jury that is unaware of the special weaknesses of evidence considered without crosscxamination. See Morgan \& Maguire, Looking Backward and Forward at Evidence, 50 Harv. L. Rev. 909, 919 (1937) (characterizing Wigmore's view); Weinstein, Probative Force of Hearsay, 46 Iowa L. REv. 331, 334-36 (1961) (listing three factors said to underlic hearsay rule); $c f$. Bruton v. United States, 391 U.S. 123, 138 (1968) (Stewart, J., concurring) (risk of overvaluation of evidence sajd to underlic confrontation clause of Sixth Amendment). But sec Morgan, The Jury and the Exclusionary Rules of Evidence, $4 \mathrm{U}$. Chi. L. Rev. 247 (1937).

The risk of prejudice of this general type has been noted recently by the Supreme Court in United States v. Hale, 422 U.S. 171 (1975), in which the Court reversed a conviction on the ground that the prosecutor had attempted to impeach the defendant's testimony by referring to defendant's silence at the time of arrest. According to the Court, "a significant potential for prejudice" lay in the fact "that the jury is likely to assign much more weight to the defendant's previous silence Ihan is warranted." Id. at 180 (emphasis aclded). 
believed to be tainted by some fundamental personal evil. ${ }^{66}$ Similarly, the jury may draw an inference from evidence of protected speech or association to a more specific propensity to commit the crime charged and may endow that inference with a strength not reasonably warranted by the evidence. ${ }^{67}$ This danger is particularly acute when inferences of criminality are drawn from association with a specific group, and when the inferences are based not on evidence introduced at trial but rather on the jury's own views of the group in question, drawn from out-of-court sources. ${ }^{68}$ In times of political tension, there is a substantial likelihood that information from such sources will be used, consciously or unconsciously, to impute an undue propensity to specific crimes to members of well-known and offensive political groups.

If prejudicial inferences of this type are drawn from evidence of protected speech, a heavy burden is imposed upon the exercise of First Amendment rights. The burden so placed on First Amendment rights is not unlike the burden on Fifth Amendment rights found unconstitutional by the Supreme Court in Griffin $v$. California. ${ }^{69}$ In Griffin the Court held that comment by the trial judge or the prosecutor on the defendant's failure to take the stand-comment that explicitly invited the jury to draw an adverse inference from the defendant's failure to testify-infringed the defendant's Fifth Amendment rights. The Court noted that such comment "is a penalty imposed by courts for exercising a constitutional privilege. It cuts down on the privilege by making its assertion costly." 70 The drawing of an undue

66. See note 56 supra.

67. Thus, general statements of approval of the policies of a foreign country may slightly increase the probability that the speaker might commit espionage or other criminal acts on behalf of that country; yet in times of political tension, popular feeling may endow such an inference with undue strength.

68. Such a danger appears to have been present in the Rosenberg trial. See note 52 supra. It should be no more permissible for a finder of fact to use out-of-court sources for the purpose of imputing supposed attributes to a specific group or to a particular member of that group than it is for a finder of fact to determine the nature of a defendant from what he has heard about that individual from out-of-court sources. See p. 1637 \& note 4 supra.

69. 380 U.S. 609 (1965).

70. Id. at 614. It is noteworthy that in Griffin the trial court's explicit sanctioning of the questionable inference was held impermissible, at least in part on the ground that the jury might draw an erroneously strong inference of guilt from the defendant's failure to take the stand. Id. at 614-15. See also United States ex rel. Macon v. Yeager, 476 F.2d 613 (3d Cir.), cert. denied, 414 U.S. 855 (1973) (prosecutor's comment on defendant's telephone call to lawyer on morning after crime held unconstitutional penalty on defendant's exercise of Sixth Amendment rights because it suggested that guilt might be inferred from consultation with counsel). 
inference of guilt from protected speech is similarly a penalty, imposed here by the jury for exercising a constitutional right. ${ }^{71}$

\section{The Chilling Effect}

One further burden may be imposed upon First Amendment rights when evidence of protected speech or association is introduced against a criminal defendant. In certain types of prosecutions, the introduction of such evidence may exert a "chilling effect" on the speech or association of other persons, who will fear that evidence of their own controversial political activity may be introduced against them if they should be prosecuted for a similar offense. ${ }^{72}$ Substantial danger of chilling protected expression may be present, for example, if protected public speech can be introduced in the trial of the speaker on charges of planning or organizing disturbances that may occur before or after the speech in question..$^{73}$ Thus in the Chicago Eight prosecution, much of the Government's evidence that the defendants had conspired to cross state lines to plan or incite riots was composed of films and testimony concerning public speeches given by the defendants and others before and during demonstrations in Chicago at the time of the Democratic National Convention. ${ }^{74}$ The nature of the possible chilling effect on future speech is suggested by the remarks of one of the defendants in that case:

71. The dangers posed by a penalty of this sort are not mitigated by the fact that, since the drawing of an unduly strong inference of guilt is largely an unconscious process, the jury itself will not perceive that a penalty is being imposed on protected speech or association.

72. On the place of the "chilling effect" in First Amendment doctrine, see Note, The Chilling Effect in Constitutional Law, 69 Colum. L. REv. 808, 809-32 (1969); Note, The First Amendment Overbreadth Doclrine, 83 HARv. L. REv. 844, 852-58 (1970); Note, Overbreadth Review and the Burger Court, 49 'N.Y.U.L. REv. 532 (1974).

73. Professor Emerson has commented that

expression may be seriously inhibited when the speaker knows that what he says can be used against him at a later time if some unforeseen action ensues, can be taken into account by a jury in determining his state of mind in performing a subsequent act, or can perhaps be the decisive factor in a jury's general verdict against him.

T. EMErsox, supra note 4, at 405. See also Note, The First Amendment Overbreadth Doctrine, 83 HARv. L. REv. 844, $926 \mathrm{n} .325$ (1970) (in certain conspiracy prosecutions, "[s]ubmission of evidence of public advocacy to the jury as probative of guilt may create the same sort of chill as a statute that by terms prohibits advocacy"); Note, Conspiracy and the First Amendment, 79 YALE L.J. 872, 894 (1970) ("The chilling effect caused by the use of protected expression as evidence in a conspiracy trial is the same as that which flows from prosecuting an individual for the specch itself.")

74. United States v. Dellinger, 472 F.2d 340, 394-407 (7th Cir. 1972), cert. denied, 410 U.S. 970 (1973). See also Pcople v. Epton, 19 N.Y.2d 496, 503, 227 N.E.2d 829, 833, 281 N.Y.S.2d 9, 14 (1967), appeal dismissed and cert. denied, 390 U.S. 29 (1968) (defendant's public speeches introduced in trial on charges of planning riots in Harlem in 1964). 
Whatever we said in peaceful assemblies, in churches, or to the news media was eventually collected as part of the evidence proving our guilt for what finally happened in Chicago.

The dangers of this doctrine are obvious. ... [U]nder the doctrine a spokesman becomes responsible for any violence or illegal activity occurring at a demonstration he plans or encourages. If it can be proven that you have a defiant and rebellious "state of mind," you can be indicted even if your only concrete act is bringing people on a bus to Chicago. ${ }^{75}$

As a practical matter it may be difficult to prove the "chilling effect" of any particular governmental burden on speech; yet statutes have frequently been struck down on the ground that they discouraged protected speech, without any requirement that such an effect be shown by specific proof or more general empirical evidence. ${ }^{76}$ In a number of instances of overbreadth adjudication, the Court has in effect assumed that a statute will chill protected speech even where there is a strong likelihood that any chilling effect is not particularly severe. ${ }^{77}$ The Court has thus frequently guarded against the risk of a chilling effect that may undetectably discourage protected speech.

\section{B. Lessening the Risk of First Amendment Violations}

One or more of the foregoing burdens may be imposed whenever evidence of protected expression is introduced against a criminal defendant. The danger is particularly severe in times of political tension when evidence of especially disfavored views or associations may be considered by a jury. In any particular case, however, it is ordinarily impossible to know whether the jury has retaliated against the defendant or has drawn an unduly strong inference from the defendant's protected speech or association to his guilt of the offense charged. Either of these violations of the First Amendment would ordinarily be concealed in the jury's general verdict of guilty, since, as a practical matter, it is rarely possible to determine the precise considerations on which a jury's decision is based. Furthermore, the policy of protecting the confidentiality of jury deliberations has prompted comprehensive

75. T. HAYdeN, Trial 25 (1970).

76. See, e.s., Talley v. California, 362 U.S. 60 (1960) (ordinance requiring identification of author of handbills unconstitutionally discourages protected spcech). For an exception, see Buckley v. Valeo, 424 U.S. 1, 72-74 (1976) (minority partics not protected from compelled disclosure of contributors, required under federal election law, in the absence of proof of "reasonable probability" of harassment).

77. For recent examples, see Lewis v. City of New Orleans, 415 U.S. 130 (1974); Gooding v. Wilson, 405 U.S. 518 (1972). 
rules designed to insulate the jury's decision from attack on the ground that it was motivated by improper factors. ${ }^{78}$ Thus while it may sometimes be possible to detect decisions by mayors or other public officials to penalize protected speech, an analogous determination with respect to juries is ordinarily impossible. ${ }^{79}$

Since it is not possible to determine whether any specific conviction rests on the jury's penalization of protected expression, First Amendment interests can be protected only by measures designed to lessen the risk that the jury may decide a case on such a basis. Under traditional evidentiary theory, such a goal might conceivably be achieved either by requiring appropriate limiting instructions to the jury or by excluding from the trial some or all evidence of the defendant's protected speech or association.

It seems clear that limiting instructions do not provide an adequate safeguard. Even in theory, limiting instructions could be used to guard only against retaliation and the clearest forms of unduly strong inferences from protected speech; $^{\mathbf{s 0}}$ it would seem impossible to frame a clear instruction that would guard against the subtler but still very potent possibility of an inflated assessment of the strength of the evidence. Even more importantly, courts and commentators have long acknowledged the dubious effectiveness of limiting instructions for

78. FED. R. EvID. 606(b), for example, disqualifies a juror from testifying "to the effect of anything upon his or any other juror's mind or emotions as influencing him to assent to or dissent from the verdict ... or concerning his mental processes in connection therewith," except with respect to information or influences from sources outside the courtroom. See Williams v. State, 204 Mcl. 55, 65-72, 102 A.2d 714, 719-22 (1954) (Sobeloff, C.J.) (reviewing history and justification of rule against jury self-impeachment). See gencrally $8 \mathrm{~J}$. WigmoRe, supra note 19, at $\$ S$ 2346-56 (McNaughton Rev. 1961).

The possibility of undetectable prejudicial use of evidence is not solely a function of the law's reluctance to monitor or reveal the jury's deliberations. The extent to which the jurors are in fact making impermissible use of evidence may not even be clear to the jurors themselves. See H. Kalven \& H. Zeiscl, The AMerican JurY 87 (1966). The fact that First Amendment prejudice may be subtle, however, does not mean that it is not effective or does not require prophylactic rules to reduce the substantial risks that it raises.

79. If a school board impermissibly takes protected speech into account in discharging a teacher, the board might still prevail in resulting civil litigation, if it can prove that the teacher would have been discharged for reasons independent of the speech in question. Mt. Healthy City School Dist. Bd. of Educ. v. Doyle, 97 S. Ct. 568, 575-76 (1977). Analogous inquiry and proof, however, seem out of the question with respect to a general verdict of guilty handed down in a criminal case in which evidence of defendant's protected activity has been submitted to the jury.

80. Thus, in C'nited States $v$. Rosenberg, the trial court instructed the jury that eridence of Communist Party membership did not in itself constitute sufficient evidence upon which a conviction could be based. See note 52 supra. Similarly, the court might have specifically instructed the jury to consider only evidence of the nature of the Communist Party presented in court, and not any information on that subject derived from out-of-court sources. Such an instruction, while at least intelligible, would probably have had little if any practical effect. 
the purpose of eliminating or reducing severe dangers of prejudice. ${ }^{81}$ Moreover, in notable instances the Supreme Court has found that limiting instructions are insufficient to safeguard specific constitutional rights against improper actions by juries. ${ }^{82}$

An exclusionary rule of evidence is therefore the only effective technique for insulating the defendant from the violations of the First Amendment discussed here. Thus it is necessary to consider whether the present standard for the exclusion of prejudicial evidence, under which evidence is admitted unless its prejudicial force substantially outweighs its probative value, affords adequate protection to First Amendment values or whether, on the contrary, a more stringent rule of exclusion should be applied when evidence of protected speech or association is introduced against a criminal defendant.

A more stringent rule of exclusion, designed to safeguard First Amendment interests, would increase the difficulty of introducing evidence of protected speech or association against a criminal defendant, even though the evidence is relevant to one or more elements of the offense charged. In some instances, therefore, the government may lose the benefit of legitimate inferences to be drawn from the evidence in question, in order to decrease the risk that protected expression will be penalized in one or more of the ways discussed above. The imposition of such a prophylactic rule must rest on the decision that, to some extent, other governmental values must be subordinated in order to assure more effectively that First Amendment values are not burdened.

Such a special prophylactic rule would well accord with First Amendment doctrine developed in other contexts. The Supreme Court has frequently imposed special prophylactic rules which have the effect of impeding the achievement of legitimate governmental goals in order to decrease the risk that protected speech will be improperly

81. E.g., Krulewitch v. United States, 336 U.S. 440, 453 (1949) (Jackson, J., concurring) ("The naive assumption that prejudicial effects can be overcome by instructions to the jury . . . all practicing lawyers know to be unmitigated fiction."); E. MORGAN, SoME Problems of Proof under the ANglo-American System of Litigation 105 (1956). Compare the following assessment by Judge Frank:

What a crop of subsidiary semi-myths and mythical practices the jury system yiclds! Time and money and lives are consumed in debating the precise words which the judge may address to the jury, although everyone who stops to see and think knows that these words might as well be spoken in a forcign language-that, indeed, for all the jury's understanding of them, they are spoken in a forcign language. . . .

Do not those unintelligible words uttered by the judge in the presence of the jury resemble the talismanic words of Word-Magic? . . .

J. Frank, LAw AND ThE Modern Mind 181 (1935) (footnotes omitted).

82. See Bruton v. United States, 391 U.S. 123 (1968); Jackson v. Denno, 378 U.S. 368 (1964). But see Harris v. New York, 401 U.S. 222 (1971). 
burdened. Procedural rules of particular stringency are required where First Amendment values are threatened, in recognition of the fact that First Amendment rights form the "matrix, the indispensable condition" of other constitutional freedoms. ${ }^{s 3}$ A special set of rules has been imposed, for example, when a proceeding may result in a "prior restraint" on speech or association. ${ }^{84}$ These rules reflect the view that procedural safeguards more stringent than those otherwise required by due process must be employed when there is a risk that First Amendment rights may be erroneously infringed..$^{85}$

So crucial, in fact, is the procedural protection of speech that even the safeguards required by another specific constitutional right may not always suffice when speech is involved. Thus, although the Fourth Amendment provides restrictions on searches and seizures, the First Amendment requires even more stringent procedures when the material to be seized includes items, such as books or films, that may constitute protected speech. Accordingly, the First Amendment imposes its own, more stringent, limitations on warrantless seizures ${ }^{8 \mathfrak{c}}$

83. Palko v. Connecticut, 302 U.S. 319, 327 (1937). See generally Cahn, The Firstness of the First Amendment, 65 YALE L.J. 464 (1956); McKay, The Preference for Freedom, 34 N.Y.U.L. REv. 1182 (1959); Monaghan, First Amendment "Due Process," 83 HARv. L. REv. 518 (1970).

84. The procedures required for the censorship of films, for example, are set out in Freedman v. Maryland, 380 U.S. 51, 57-60 (1965) (requiring that final determinations of obscenity be made by court, rather than administrative body, even though proceeding is not criminal in nature; that censor bear burden of proving obscenity; and that judicial determination be made as quickly as possible). "The teaching of our cases is that, because only a judicial determination in an adversary proceeding ensures the necessary sensitivity to freedom of expression, only a procedure requiring a judicial determination suffices to impose a valid final restraint." Id. at 58. See Southeastern Promotions, Ltd. v. Conrad, 420 U.S. 546, 560, 562 (1975) (Freedman procedures required of municipal theater before rejecting application of allegedly obscene play); United States $v$. ThirtySeven Photographs, 402 U.S. 363, 367-75 (1971) (same in seizures by customs agents); Blount v. Rizzi, 400 U.S. 410,421 (1971) (same in postal censorship).

Special First Amendment limits have also been placed on the ability of the states to secure ex parte restraining orders against parades, demonstrations, and other conduct related to speech, even though such orders may be perfectly proper when speech or association is not involved. Carroll v. President and Comm'rs, 393 U.S. 175, 180, 184 (1968).

85. See Bantam Books, Inc. v. Sullivan 372 U.S. 58, 66 (1963).

86. In Roaden v. Kentucky, 413 U.S. 496 (1973), the Supreme Court held that a police officer who believes that he has seen an obscene film may not make a warrantless seizure of the film, even incident to the arrest of the exhibitor.

The seizure is unreasonable, not simply because it would have been easy to secure a warrant, but rather because prior restraint of the right of expression, whether by books or films, calls for a higher hurdle in the evaluation of reasonableness. ... [W] examine what is "unreasonable" in the light of the values of freedom of expression.

Id. at 504 (emphasis added). See Flack v. Municipal Court, 66 Cal. 2d 981, 990-91, 429 P.2d 192, 198, 59 Cal. Rptr. 872, 878 (1967) ("While it is settled that in the ordinary case a search incident to an arrest is not 'unreasonable' if the arrest itself is lawful ... the First Amendment compels more restrictive rules in cases in which the arrest and scarch relate to alleged obscenity." (citations omitted)). 
and its own requirements for obtaining a search warrant. ${ }^{87}$ Further, the Supreme Court has required a heightened degree of specificity in a search warrant's description of "things to be seized" when those " 'things' are books, and the basis for their seizure is the ideas which they contain." 88 The First Amendment thus requires procedural protection superseding that provided by another constitutional right.

Another way in which the Supreme Court has given First Amendment rights special protection is by shifting burdens of persuasion and by increasing standards of proof in order to give speech greater protection than otherwise required by due process. These doctrines rest on the belief that, if error is to occur in the First Amendment context, it is better to err in favor of speech and that the state must sometimes forgo proper penalization of unprotected activity in order to assure that protected speech is not erroneously burdened.

In the leading case of Speiser $v$. Randall, , $^{89}$ for example, the Court struck down a provision requiring that, as a condition of receiving a veteran's property tax exemption, a taxpayer bear the burden of proving that he did not advocate the violent overthrow of the government. Ordinarily the state may require a taxpayer to bear the burden of proof on all questions of liability for taxes.90 Where governmental action threatened to penalize expression, however, "the transcendental value of speech" required that the burden be shifted to the government. Shifting the burden of proof to the government may sometimes result in protection being erroneously extended to unprotected speech. Nevertheless, the otherwise valid governmental interest must give way before the more powerful imperatives of the First Amendment.

The basic principle of Speiser $v$. Randall was reaffirmed in New

87. A judicial warrant for the seizure of books may not rest "on the strength of the conclusory assertions of a single police officer, without any scrutiny by the judge of any materials considered . . . to be obscene." Marcus v. Search Warrant, 367 U.S. 717, 731-32 (1961) (alternate holding). Further, a judicial warrant for the seizure of a film may not be issued "solely upon the conclusory assertions of the police officer [who viewed the film] without any inquiry by the justice of the peace into the factual basis for the officer's conclusions." Lee Art Theatre, Inc. v. Virginia, 392 U.S. 636, 637 (1968) (per curiam).

88. Stanford v. Texas, 379 U.S. 476, 485 (1965). As Justice Harlan remarked, where books are seized, "the most 'scrupulous exactitude' is demanded in the warrant's description; ... but where the special problems associated with the First Amendment are not involved .... a more 'reasonable particularity,' . . . is permissible." Berger v. New York, 388 U.S. 41, 98 (1967) (Harlan, J., dissenting). See also A Quantity of Copies of Books v. Kansas, 378 U.S. 205 (1964) (plurality opinion); Marcus v. Search Warrant, 367 U.S. 717, 732 (1961).

89. 357 U.S. 513 (1958).

90. Id. at 523-24. 
York Times Co. v. Sullivan. ${ }^{91}$ There the Supreme Court held that, under the First Amendment, public officials suing for libel must bear the burden of proving that the defendant's statements were made with knowing falsity or reckless disregard of the truth. ${ }^{92}$ In contrast, the pre-existing state rule had placed the burden of proving "truth" on the defendant. The Court thus relieved the speaker of the effective burden of proving whether or not the speech is insulated from liability and imposed that burden on the party seeking to penalize the speech in question. ${ }^{83}$

The Court, moreover, has required an unusually high standard of proof in order to guard First Amendment interests against an erroneous finding of fact. A public official who sues for libel, for example, must prove "actual malice" with "convincing clarity," in contrast to the less exacting "preponderance" test ordinarily applicable in tort litigation. ${ }^{94}$ The higher standard of proof is necessary because "an erroneous judgment of liability is, in view of the First Amendment values at stake, of more serious concern than an erroneous judgment in the opposite direction . . . ."95

91. 376 U.S. 254 (1964).

92. Id. at 279-80.

93. Speiser $v$. Randall was also followed in Freedman v. Maryland, 380 U.S. 51 (1965), in which the Court held that a state censorship board must bear the burden of instituting proceedings for a restraining order and must bear the burden of persuasion on the question of obscenity; and, more recently, in Healy v. James, 408 U.S. 169, 184 (1972), in which the Court made clear that a state college must bear the burden of showing that a student political organization was not entitled to recognition.

94. New York Times Co. v. Sullivan, 376 U.S. 254, $285-86$ (1964). See Gertz v. Robert Welch, Inc., 418 U.S. 323, 342 (1974); Vandenburg v. Newsweek, Inc., 507 F.2d 1024, 1026 (5th Cir. 1975) ("evidence of actual malice must be clear and convincing, more than a preponderance").

Similarly, in denaturalization proceedings resting on the citizen's alleged lack of "attachment" to the principles of the Constitution, that allegation must be established by "clear and unequivocal" proof, at least in part because First Amendment values are at issue. Schneiderman v. United States, 320 U.S. 118, 135 (1943). See McKay, supra note 83, at 1222 n.179. Cf. Knauer v. United States, 328 U.S. 654 (1946) (same standards apply to proof of fraud in swearing oath of allegiance to United States); Baumgartner v. United States, 322 U.S. 665, 670 (1944) (same).

95. Time, Inc. v. Firestone, 424 U.S. 448,472 n.2 (1976) (Brennan, J., dissenting). Particularly strict appellate scrutiny of the sufficiency of evidence has been undertaken by the Supreme Court in reviewing libel judgments under the New York Times standard, as well as in other areas in which there may be a substantial risk that finders of fact might not apply First Amendment doctrines with sufficient understanding. E.g., Old Dominion Branch No. 496, Nat'l Ass'n of Letter Carriers v. Austin, 418 U.s. 264, 282 (1974). Such action reflects distrust of the ability or willingness of the jury to give adequate protection to First Amendment values. Similar First Amendment concerns have dictated a heightened readiness to grant summary judgments against plaintiffs in defamation cases, a practice that results in removing the decision from juries and avoiding the chilling effect of long and expensive trials. See, e.g., Guitar v. Westinghouse Elec. Corp., 396 F. Supp. 1042, 1053 \& n.16 (S.D.N.Y. 1975), aff'd mem., 538 F.2d 309 (2d Cir. 1976) ("because of the importance of free speech, summary judgment is the 'rule,' and not the exception, in defamation cases" (citing cases)). 
A further way in which the First Amendment is given special procedural protection is by the relaxation of traditional rules of standing. In a long line of cases following Thornhill $v$. Alabama,"13 the Supreme Court has held that a speaker who is prosecuted (or subjected to another governmental burden) under an "overbroad" statute-a statute that prohibits both protected and unprotected speech or related conduct-may raise the overbreadth of the entire statute as a defense, even though his own conduct might not be constitutionally protected.$^{97}$ In a criminal case, for example, the defendant is acquitted and the statute invalidated even though the defendant's speech or conduct might constitutionally have been penalized under a more narrowly drawn statute. 98

The overbreadth doctrine rests principally on the concern that the mere existence of overbroad statutes will exert a chilling effect on protected speech by posing a continuing threat of prosecution. Rules of standing are therefore relaxed in order to secure an early invalidation of overbroad statutes. ${ }^{99}$ This doctrine of First Amendment overbreadth is an extraordinary technique: in most other areas a litigant whose conduct is not constitutionally protected has no standing to attack a statute on the ground that it might be applied, in some future case, to constitutionally protected activity. ${ }^{100}$ The doctrine again reflects the judgment that special rules are necessary to protect rights of expression. "In the end, this departure from the normal method of judging the constitutionality of statutes must find justification in the favored status of rights to expression and association in the constitutional scheme."101

96. 310 U.S. 88 (1940).

97. E.g., Gooding v. Wilson, 405 U.S. 518 (1972); United States v. Robel, 389 U.S. 258 (1967); Keyishian v. Board of Regents, 385 U.S. 589 (1967).

98. The sweep of the First Amendment overbreadth doctrine has been limited to some extent by Broadrick v. Oklahoma, 413 U.S. 601 (1973), in which the Court held that a statute would be held invalid only if "substantially" overbroad and elaborated a sliding scale to determine substantiality. The doctrine of "substantial" overbreadth may, however, have been implicit in earlier overbreadth decisions. See Note, The First Amendment Overbreadth Doctrine, 83 HaRv. L. REv. 814, 918-27 (1970). Morcover, it has becn argued that, "[i]n light of [Lewis v. City of New Orleans, 415 U.S. 130 (1974)], it appears that Broadrick's only real impact will be on adjudication involving statutes which regulate [speech-related] conduct rather than speech." Note, Overbreadth Review and the Burger Court, 49 N.Y.U.L. Rev. 532, 544 (1974). But see Bates v. State Bar, 97 S. Ct. 2691, 2707-08 (1977) (overbreadth doctrine held inapplicable to professional advertising, "a context where [the doctrine] is not necessary to further its intended objective").

99. Note, The First Amendment Overbreadth Doctrine, 83 HARv. L. REv. 844, 85355 (1970).

100. Id. at 852 \& $\mathrm{n} .33$.

101. Id. at 852 (footnotes omitted).

In addition to the chilling effect rationale, it has been asserted that this First Amendment technique also rests, to some extent, on the Court's wish to minimize the risk of 
Similar considerations have also resulted in the creation of a special First Amendment doctrine of vagueness. Although the doctrine of vagueness has long been applied as a general constituent of due process, ${ }^{102}$ its particularly strict application to statutes concerning speech clearly marks the doctrine as another special First Amendment prophylactic technique. "Due process requires that a criminal statute provide adequate notice to a person of ordinary intelligence that his contemplated conduct is illegal .... Where First Amendment rights are involved, an even 'greater degree of specificity' is required."103

Finally, in reviewing convictions for group activity related to political association, courts have created special First Amendment evidentiary rules, more stringent than those ordinarily required by due process, to restrict the inferences that may be drawn from evidence of political association. The special First Amendment rules are derived from the Supreme Court's requirement that, in order to es-

undetectable retaliation against the content of speech on the part of law enforcement officers and triers of fact. Note, The First Amendment Overbreadth Doctrine, 83 HARv. L. Rev. 844, $872-73$ (1970). See Thornhill v. Alabama, 310 U.S. 88, 97-98 (1940) (overbroad statute "lends itself to harsh and discriminatory enforcement by local prosecution officials, against particular groups deemed to merit their displeasure"). Similar fears underlic numerous decisions striking down statutes that grant broad power to administrators to license parades, public meetings, and other speech-related activities, without sufficiently narrow standards based on neutral criteria such as the flow of traffic, the ordinary use of the area, and so on. Staub v. City of Baxley, 355 U.S. 313 (1958) (permit for solicitation of organization membership); Kunz v. New York, 340 U.S. 290 (1951) (permit for public worship); Saia v. New York, 334 U.S. 558 (1948) (permission for use of loudspeaker); Schneider v. State, 308 U.S. 147 (1939) (four cases) (permits for distribution of literature); Lovell v. City of Griffin, 303 U.S. 444 (1938) (permit for distributing literature).

These "overbreadth" decisions rest on the fear that such broad discretion creates a risk that the licensing official may impermissibly base his decision on the content of the prospective speech. Although such a decision would violate First Amendment principles, it could often be masked by a plausible rationalization based on neutral factors, and thus would evade effective judicial review. Saia v. New York, 334 U.S. 558, 562 (1948). To guard First Amendment rights against such undetectable retaliation, the Court has employed the unusual remedy of invalidating the statute on its face.

102. See, e.g., Lanzetta v. New Jersey, 306 U.S. 451 (1939) (statute prohibiting association with "any gang consisting of two or more persons" held unconstitutionally vague).

103. Buckley v. Valeo, 424 U.S. 1, 77 (1976) (per curiam).

The vagueness doctrine has additional bearing here since it also rests in part on the fear that governmental officers, including juries, acting under the cover of vague statutes, may retaliate in an undetectable manner against the content of protected speech. See Smith v. Goguen, 415 U.S. 566, 575-76 (1974); Shelton v. Tucker, 364 U.S. 479, 492 (1960) (Frankfurter, J., dissenting) (certain vague statutes, by "prescribing indefinite standards of guilt ... [allow] the potential vagaries and prejudices of juries, effectively insulated against control by reviewing courts, the power to intrude upon the protected sphere"); Note, The Void-for-Iagueness Doctrine in the Supreme Court, 109 U. PA. L. REv. 67, 104-09 (1960). In order to reduce the danger of undetectable governmental retaliation, a vague statute is invalidated on its face. The special doctrine of First Amendment vagueness thus suggests that when dangers of undetectable retaliation against protected speech are present, First Amendment doctrine has required procedural rules of increased stringency in order to decrease the risk that such retaliation will be undertaken. 
tablish an offense under the membership clause of the Smith Act, ${ }^{104}$ the government must show not only that the defendant is an "active" member of an organization advocating action directed toward the violent overthrow of the government, ${ }^{105}$ but also that the defendant, as an individual, possesses the specific intent to accomplish the illegal goals of the organization. ${ }^{106}$ In order to guard against the danger of an erroneous finding of specific intent, the Court emphasized that an unusually rigorous standard of proof must be satisfied in order to assure the presence of substantial evidence bearing on each independent element of the membership offense:

[I]t should ... be said that ... [the specific intent] element of the membership crime, like its others, must be judged strictissimi juris, for otherwise there is a danger that one in sympathy with the legitimate aims of such an organization, but not specifically intending to accomplish them by resort to violence, might be punished for his adherence to lawful and constitutionally protected purposes, because of other and unprotected purposes which he does not necessarily share. ${ }^{107}$

In other words, courts must take particular pains to assure that there is substantial evidence of the specific intent required to link the individual with the illegal goals of the group. The fundamental policies of the First Amendment dictate this increased care to assure that defendants are not in fact being penalized for protected speech or association, particularly in light of the subtlety and complexity of the Smith Act offenses. ${ }^{108}$

A number of lower courts have elaborated and sharpened the Supreme Court's strictissimi juris standard. In Hellman v. United States, ${ }^{109}$ for example, the Ninth Circuit Court of Appeals clarified the principle, implicit in Scales v. United States ${ }^{110}$ and Noto v. United

104. 18 U.S.C. $\$ 2385$ (1970).

105. Scales v. United States, 367 U.S. 203, 221-30 (1961).

106. Id. See also Keyishian v. Board of Regents, 385 U.S. 589, $605-10$ (1967); Elfbrandt v. Russell, 384 U.S. 11 (1966).

107. Noto v. United States, 367 U.S. 290, 299-300 (1961). Correlatively, the Court in Scales, decided on the same day as Noto, required that there be "clear proof" of the defendant's proscribed specific intent in order to uphold the conviction. 367 U.S. 203, 229 (196I).

108. See Scales v. United States 367 U.S. 203, 232 (1961). The Court in Scales and Noto also undertook an unusually stringent review of the facts on which the convictions rested. However, the Court did not focus on the need to exclude certain evidence of protected speech in order to achieve protection for First Amendment interests. In fact, in considering a question of admissibility of evidence, the Court in Scales appears to have endorsed the traditional balancing technique with minimal appellate review. $I d$. at 250 . See also Street v. New York, 394 U.S. 576, 594 (1969).

109. 298 F.2d 810 (9th Cir. 1961).

110. 367 U.S. 203 (1961). 
States, ${ }^{111}$ that the government must introduce independent evidence of the defendant's specific intent in order to secure a conviction under the membership clause of the Smith Act. To base a finding of a defendant's individual intent upon "the facts of active membership and knowledge of the illegal aims of the Party" would not take into account the "possibility of an entirely innocent intent," and would risk penalizing political association alone.112 Whatever conclusions might be drawn from active and knowing group participation when political expression is not at issue, the strictissimi juris standard requires a more specific showing where such expression is at issue.

In order to implement this restrictive standard, the court in Hellman imposed further limitations on the inferences that could be drawn even from the action or speech of the defendant himself. Thus, inferences drawn from the defendant's own Communist Party activity would suffice to show the proscribed specific intent only if the Party activity "was of a kind which is explainable on no other basis than that [the defendant] personally intended to bring about the overthrow of the Government as speedily as circumstances would permit."113 This standard is substantially more exacting than the corresponding rule in an ordinary criminal case, which permits conviction even if possible inferences from the evidence were consistent with innocence, so long as a jury could reasonably have concluded that guilt was established beyond a reasonable doubt. The Hellman standard thus prohibits, as a matter of federal free speech law, conclusions of a nature that are ordinarily permitted in cases in which First Amendment values are not threatened.114

111. 367 U.S. 290 (1961).

112. 298 F.2d at 812 .

113. Id. at 813 (emphasis added). Similarly, defendant's own statements would not suffice for a finding of proscribed specific intent if the statements were made in defendant's "role [as] teacher of the Party line" or if the statements otherwise possessed any ambiguity on the issue of defendant's intent. Id. at 813-14. For a less stringent interpretation of this aspect of the strictissimi juris rule, see United States r. Dellinger, 472 F.2d 340, 380 (7th Cir. 1972), cert. denied, 410 U.S. 970 (1973).

114. The court's reversal of the conviction, after a careful review of the record, indicates the extraordinarily restrictive power of its standard. Although the court acknowledged that Hellman was an "exceedingly active member" of the Communist Partyorganizing, teaching, distributing literature, soliciting contributions-it held that this activity did not "give rise to a reasonable inference that he specifically intended to overthrow the Government by force and violence at the first propitious moment," since "the activity portrayed is explainable on the basis that he intended to bring about the Party's ultimate goals through peaceable means." 298 F.2d at 813 (emphasis added). The only Party activitics that could permissibly give rise to an inference of proscribed specific intent were such unambiguous personal actions as "the collection of weapons and ammunition in substantial quantities, or the conducting of field surveys to ascertain ways and means of sabotaging public utility or defense plants." Id. 
The doctrine of Scales and Noto was further refined in United States $v$. Spock, ${ }^{115}$ in which the defendants were convicted of conspiring to "counsel, aid and abet" Selective Service registrants in failing to retain draft cards and in obstructing the draft. ${ }^{116}$ Proof of the alleged conspiracy rested on evidence that defendants had been involved in activities protesting the Vietnam War and supporting draft resisters. ${ }^{117}$ In reviewing the convictions, the First Circuit Court of Appeals found that if there had been a conspiracy, it was "a bifarious undertaking, involving both legal and illegal conduct."118 In order to assure that adherents intending solely to further the legal goals of the undertaking were not penalized, the court imposed the following elaborate version of the strictissimi juris standard, which stringently limits the jury's ordinary freedom to draw inferences of specific intent:

When the alleged agreement is both bifarious and political within the shadow of the First Amendment, we hold that an individual's specific intent to adhere to the illegal portions may be shown in one of three ways: [1] by the individual defendant's prior or subsequent unambiguous statements; [2] by the individual defendant's subsequent commission of the very illegal act contemplated by the agreement; or [3] by the individual defendant's subsequent legal act if that act is "clearly undertaken for the specific purpose of rendering effective the later illegal activity which is advocated." 119

In its elaboration of the strictissimi juris test, the Spock court thus appears to go beyond restrictions on the sufficiency of the evidence to impose special First Amendment limitations, not present in ordinary conspiracy prosecutions, on the introduction and use of evidence. ${ }^{120}$

115. 416 F.2d 165 (Ist Cir. 1969).

116. See 50 U.S.C. app. $\$ 462$ (a) (1970).

117. 416 F.2d at 168 .

118. Id. at 172 .

119. Id. at 173 (quoting Scales v. United States, 367 U.S. at 234).

120. That the Spock court contemplated a special First Amendment rule of exclusion is indicated by its treatment of evidence of statements of "third parties alleged to be co-conspirators." This evidence was apparently introduced by the Government to give rise to inferences concerning the specific intent of the defendants in adhering to the alleged conspiracy. In an ordinary conspiracy trial, analogous evidence might have been admissible under the doctrine that, if a conspiracy is found, acts and statements of some co-conspirators in furtherance of the conspiracy may be used to show intent of others. Pinkerton v. United State, 328 U.S. 610, 647 (1946) (dictum); Wiborg v. United States, 163 U.S. 632, 657-58 (1896). The Spock court, however, ruled that introduction of these statements on the issue of defendants' specific intent was "improper," since "[t]he specific intent of one defendant in a case such as this is not ascertained by reference to the 
It is clear that a more stringent rule of exclusion regarding evidence of protected speech and association would accord well with the stricter First Amendment procedural rules imposed in related areas. The importance of a special exclusionary rule is emphasized by the particular risks posed by the jury in the context of First Amendment adjudication.

It is widely acknowledged that, in general, the danger of lawless decisionmaking by government is perhaps at its greatest when the governmental agency involved is the jury. Distrust of the jury is pervasive. As Jerome Frank remarked, "I submit that the jury is the worst possible enemy of this ideal of the 'supremacy of law.' For 'jury-made law' is, par excellence, capricious and arbitrary, yielding the maximum in the way of lack of uniformity, of unknowability."121 In addition to more general problems of jury accountability, special dangers posed by the jury to First Amendment interests have frequently been noted. It has been pointed out that the jury generally represents majoritarian interests often opposed to the views of unpopular political minorities and, consequently, that the jury poses particular dangers in

conduct or statements of another even though he has knowledge thereof. . . The metastatic rules of ordinary conspiracy are at direct variance with the principle of strictissimi juris." $416 \mathrm{~F} .2 \mathrm{~d}$ at 173 (footnote omitted). Since a new trial was necessary on other grounds, however, the court did not decide whether the improper admission or use of this evidence would in itself have constituted prejudicial error requiring reversal. $I d$. at 174. Furthermore, as one commentator has noted, evidence of third-party statements might not be excluded under the Spock analysis if they were relevant to an element of the offense other than defendant's intent. Filvaroff, Conspiracy and the First Amendment, 121 U. PA. L. REv. 189, 224 \& n.140 (1972).

Nevertheless, the rule of the Spock case seems to constitute a clear First Amendment limitation on the introduction and use of evidence. Not only is evidence of the third party's statements in itself insufficient for the purpose of establishing the defendant's specific intent, it is impermissible for the jury to use it at all for that purpose. This is so even though evidence of third party statements may well possess logical relevance on that issue. If, for example, $A$ joins a political "undertaking," knowing of statements of $B$ (a leader of that group) advocating that the group undertake certain illegal acts, the probability of $A$ 's possession of proscribed specific intent would appear measurably in. creased. Yet the court's prophylactic First Amendment rule seems to prohibit the introduction of $B$ 's statements for this purpose in a prosecution for conspiracy to undertake the illegal acts. Rather, a finding of the defendant's specific intent must be based solely upon the unambiguous acts or words of the specific defendant in question.

121. J. FRANK, Covrts on TruL 132 (1949). See generally Broeder, The Funclions of the Jury: Facts or Fictions?, 21 U. ChI. L. REv. 386 (1954); Sunderland, Verdicts, General and Special, 29 Yale L.J. 253 (1920). As a result of this distrust of the jury, courts have created rules of exclusion to insulate the jury from evidence that, although relevant, poses a substantial danger of misuse. Levin \& Cohen, The Exclusionary Rules in Nonjury Criminal Cases, 119 U. P.. L. REv. 905, 905-06 (1971). Although these exclusionary rules also apply in form at least when the judge is the factfinder, their rigor is frequently mitigated in civil cases tried by a judge alone. See generally Davis, Hearsay in Nonjury Cases, 83 HARv. L. REv. 1362 (1970); Levin \& Cohen, supra. 
cases in which the rights of those groups may be infringed. ${ }^{122}$ Professor Monaghan has commented, for example:

In general, any expansive conception of the jury's role is inconsistent with a vigorous application of the first amendment. Like administrative agencies, the jury cannot be expected to be sufficiently sensitive to the first amendment interests involved in any given proceeding....

...

... Much of [the] present importance [of the first amendment] lies in protecting unpopular speech, that of Jehovah's Witnesses, Communists, fascists, radicals and the like. This development is a matter of fundamental significance, and one which requires a reevaluation of the assumption that the jury is a reliable factfinder in free speech cases. The jury may be an adequate reflector of the community's conscience, but that conscience is not and never has been very tolerant of dissent.

... [Thus] despite the Court's expansive solicitude for the jury in other contexts, first amendment considerations should be read to confine, not expand, the jury's role. ${ }^{123}$

Expressions of distrust of the jury in the protection of First Amendment rights may be found in cases involving the Supreme Court's supervision of First Amendment rules limiting recovery for libel and slander. In many of these cases the fear that a jury might covertly censor disapproved speech has led to particularly stringent appellate review of the evidence. ${ }^{124}$ In other instances, distrust of the jury has played a role in molding the substantive constitutional rule itself. Justice Harlan, a particularly thoughtful analyst of the constitutional law of libel, noted that distrust of the jury in the First Amendment context constituted a foundation of the New York Times doctrine itself:

122. Broeder, supra note 121, at 414 ("From the time of the Alien and Sedition Acts, the government's attempted inroads on civil rights scem to have received the enthusiastic support of jurors.") In a similar vein Professor Chafee remarked, "It is only in times of popular panic and indignation that freedom of speech becomes important as an institution, and it is precisely in those times that the protection of the jury proves illusory." $Z$. Chafee, Free Speech in the United States 70 (1941).

123. Monaghan, supra note 83, at $527-29$ (footnotes omitted).

124. See, e.g., Rosenbloom v. Metromedia, Inc., 403 U.S. 29, 54 (1971) (plurality opinion) ('The simple fact is that First Amendment questions of 'constitutional fact' compel this Court's de novo review.") Similarly, in reviewing Smith Act cases, courts of appeals have a special responsibility to scrutinize the evidence and to apply "rigorous standards of review." Yates v. United States, 354 U.S. 298, 328 (1957). The Supreme Court, moreover, itself ordered acquittals of certain defendants in Yates, id. at 328-31, and of the defendant in Noto v. United States, 367 U.S. 290 (1961). Dissenting in Yates, Justice Clark remarked: "In its long history I find no case in which an acquittal has been ordered by this Court solely on the facts." 354 U.S. at 346 (emphasis in original). 
[The Court recognized] that in many areas which are at the center of public debate "truth" is not a readily identifiable concept, and putting to the pre-existing prejudices of a jury the determination of what is "true" may effectively institute a system of censorship. Any nation which counts the Scopes trial as part of its heritage cannot so readily expose ideas to sanctions on a jury finding of falsity. ${ }^{125}$

Three other Justices argued in New York Times Co. v. Sullivan that a public official should never be permitted to collect libel damages from a critic of his official conduct, even if the speaker's statement was recklessly or knowingly false, since the jury cannot be relied upon to apply the standard scrupulously. ${ }^{126}$ In his concurring opinion in New York Times, Justice Black argued that the Court's First Amendment test for libel was "elusive" and "abstract" and that the jury's award probably resulted from hostility toward the defendants. "This record," continued Justice Black, "certainly does not indicate that any different verdict would have been rendered here whatever the Court had charged the jury about 'malice,' 'truth,' 'good motives,' 'justifiable ends,' or any other legal formulas which in theory would protect the press." ${ }^{27}$ The same concerns were expressed by Justice Douglas dissenting in Gertz v. Robert Welch, Inc.:

The subject matter [of an allegedly libelous publication] involved "Communist plots," "conspiracies against law enforcement agencies," and the killing of a private citizen by the police. With any such amalgam of controversial elements pressing upon the jury, a jury determination, unpredictable in the most neutral circumstances, becomes for those who venture to discuss heated issues, a virtual roll of the dice separating them from liability for often massive claims of damage.

... It matters little whether the standard be articulated as "malice" or "reckless disregard of the truth" or "negligence," for jury determinations by any of those criteria are virtually unreviewable. This Court, in its continuing delineation of variegated mantles of First Amendment protection, is, like the potential publisher, left with only speculation on how jury findings were influenced by the effect the subject matter of the publication had upon the minds and viscera of the jury. ${ }^{128}$

125. Time, Inc. v. Hill, 385 U.S. 374, 406 (1967) (Harlan, J., concurring in part and dissenting in part).

126. The three were Justices Black, Douglas, and Goldberg. See Monaghan, supra note 83 , at 527 \& $n .38$.

127. 376 U.S. at 295. See also id. at 297-305 (Goldberg, J., concurring).

128. 418 U.S. 323,360 (1974) (emphasis added). 
Although the position taken by Justices Black and Douglas has not been accepted by the Court, the validity and strength of their fears seem in large part to have been conceded sub silentio by the extreme care with which the Court has itself reviewed jury verdicts under the New York Times standard. ${ }^{129}$ And precisely these concerns over the danger of a jury's unreviewable penalization of protected speech have played a part in the decision of the Court to restrict damages without actual loss in defamation actions $\mathbf{s}^{\mathbf{1 3 0}}$ and to limit the granting of punitive damages for defamation..$^{131}$

These considerations, powerful enough in the case of libel, are even more compelling when unpopular but protected speech is entered into evidence in the prosecution of a criminal defendant. ${ }^{132}$ It thus seems clear that First Amendment doctrine should favor a stringent rule of exclusion to prevent the unreviewable burdens that juries in criminal prosecutions may impose on First Amendment values.

\section{The First Amendment Test}

When viewed against the extensive procedural protection afforded the First Amendment in other contexts, the defects in the present standard for the exclusion of prejudicial evidence seem substantial and fundamental. The essential problem is that the current test, requiring as it does that evidence be excluded only if its prejudicial force substantially outweighs its probative value, ${ }^{133}$ embodies a strong bias in favor of the admissibility of evidence. Moreover, as Judge Weinstein has recommended, courts generally apply the test in a manner favoring admissibility. ${ }^{134}$

Such an attitude may be appropriate when ordinary questions of prejudice are at issue. When the risk of prejudice, however, is a risk that First Amendment interests may be improperly penalized, the

129. See note 124 supra.

130. Gertz v. Robert Welch, Inc., 418 U.S. 323, 349 (1974).

131. Id. at 350 .

132. Improper use by the jury of evidence of protected speech or association in a criminal case may result not merely in civil damages, as in libel and slander, but rather in the most serious type of burden on First Amendment interests-the conviction of a criminal defendant based on protected speech.

133. See p. 1627 \& note 13 supra.

134. Id. See J. Wenstein \& M. Berger, Weinstein's Evidence \$ 403(03) (1976) ("Generally, the better approach on the question of admissibility is to view both probative force and prejudice most favorably towards the proponent, that is to say, to give the evidence its maximum reasonable probative force and its minimum reasonable prejudicial value.") See also Weinstein \& Berger, Basic Rules of Relevancy in the Proposed Federal Rules of Evidence, 4 GA. L. Rev. 43, 79 (1969). 
application of such a standard contrasts sharply with the premise of cases such as Speiser $v$. Randall, ${ }^{135}$ that particular pains must be taken to insulate protected speech and association from impermissible burdens.

\section{A. The Nature of the First Amendment Test}

Because such grave First Amendment risks are created when the prosecution seeks to introduce evidence of protected speech against a criminal defendant, it might be argued that evidence of protected speech should be inadmissible in a criminal trial under all circumstances. ${ }^{136}$ Such a rule would indeed make an unconstitutional conviction impossible. In general, however, First Amendment prophylactic rules are not applied with such absolute sweep. ${ }^{137}$ Moreover, doctrine in related First Amendment areas supports some degree of accommodation of permissible governmental interests. In enforcing the criminal law against nonspeech offenses, the government is involved in a traditional state function-the penalization of criminal conduct whose definition does not turn on the content of speech. In achieving this end, the state may use logically relevant evidence to give rise to permissible inferences of guilt. If evidence of protected speech is introduced in the course of proving a nonspeech offense, however, the enforcement of the criminal law may have the effect of "incidentally limiting [the] unfettered exercise [of speech]," 138 since the defendant may be penalized for his speech or future speech or may be chilled. In such cases the First Amendment may require a "reconciliation"139 of the interests of the state and the defendant, rather than a flat exclusionary rule that would always deny the government the use of permissible inferences derived from evidence of protected speech, regardless of the strength of those inferences and regardless of the remoteness of the danger that impermissible inferences might be drawn.

Such a reconciliation, however, must take account of the fact that introduction of the defendant's protected expression poses severe dangers to First Amendment rights and that other governmental interests must often give way to the procedural protection of First Amendment values. Consequently, to guard against the risk that ex-

135. 357 U.S. 513 (1958).

136. See, e.g., Note, Conspiracy and the First Amendment, 79 YALE L.J. 872, 894-95 (1970) (protected public expression should be excluded in conspiracy prosecutions).

137. For example, overly broad statutes affecting speech are constitutional if the degree of overbreadth is not "substantial" under the circumstances. Broadrick v. Oklahoma, 413 U.S. 601 (1973).

138. Konigsberg v. State Bar, 366 U.S. 36, 50 (1961).

139. Id, at 51 . 
pression protected by the First Amendment will be used impermissibly to penalize a criminal defendant, evidence of a defendant's protected speech or association should be excluded, when offered by the government, unless the government can establish that the probative value of the evidence substantially outweighs its prejudicial dangers. This standard, which reverses the ordinary test and imposes a heavy burden on the government, would afford substantial protection to First Amendment interests. Yet the standard would also permit the government to use such evidence if the permissible inferences to be drawn from the evidence are extremely strong and if the introduction of the evidence is essential to proof of an offense that is not itself based on protected speech.

\section{B. Parallel Tests in Legislative and Other Investigations}

The use of a test that imposes a heavy burden of justification on the government would parallel developments in the law of legislative investigations and related areas, in which First Amendment values have overridden the interest of the government in obtaining information about an individual's protected speech or association. Cases in the 1950s and early 1960s used a balancing test that gave presumptive weight to governmental interests in obtaining disclosure of protected speech and association. ${ }^{140}$ But more recent cases have insulated witnesses from forced disclosure of protected association in opinions in which language requiring the showing of a "compelling" governmental interest has been prominent. ${ }^{111}$ As Professor Emerson has stated,

more likely, the balancing test as a whole has undergone transformation as the Court has come to give greater weight to the

140. E.g., Braden v. United States, 365 U.S. 431 (1961) (refusal to answer questions about Communist Party membership); Wilkinson v. United States, 365 U.S. 399 (1961) (same); Barenblatt v. United States, 360 U.S. 109 (1959) (same); Uphaus v. Wyman, 360) U.S. 72 (1959) (refusal to disclose names of guests at summer camp suspected of connection with "subversive activities").

14l. E.g., Gibson v. Florida Legislative Investigation Comm., 372 U.S. 539 (1963) (NAACP official protected in refusing to refer to membership records to determine whether individuals supposedly affiliated with Communist Party were also members of NAACP). See also DeGregory v. Attorney Gen., 383 U.S. 825 (1966) (witness protected in refusing to discuss Communist Party activities six years earlier); Pollard v. Roberts, 283 F. Supp. 248 (E.D. Ark.), aff'd per curiam, 393 U.S. 14 (1968) (disclosure of contributors to Arkansas Republican Party protected against subpoena by prosecutor investigating purchasing of votes).

"Compelling interest" language was also used by the Court in decisions insulating the anonymity of NAACP membership at a time when Communist Party affiliations were subjected to disclosure under a balancing test more lenient to the government. Bates r: City of Little Rock, 361 U.S. 516, 524 (1960); NAACP v. Alabama, 357 U.S. 449, 463 (1958). 
First Amendment side of the balance. In any event the balancing test has taken the form of requiring the government to show a "subordinating" interest that is "compelling." In this version the test comes close to putting the burden of persuasion on the government and establishing a presumption in favor of First Amendment rights. ${ }^{142}$

A "compelling interest" test that places a substantial burden on the government has also been used to insulate protected speech and association from grand jury inquiries. In Bursey $v$. United States, ${ }^{143}$ the Ninth Circuit held that the First Amendment protected staff members of a Black Panther newspaper from disclosing information about the organization of the newspaper, even though that information may have been useful to a grand jury investigating threats to assassinate the President and other crimes. The court of appeals squarely rejected the Government's assertion that the First Amendment possesses no effective force in grand jury proceedings ${ }^{144}$ and, striking the constitutional balance, pitched the applicable test sharply against the Government. "When governmental activity collides with First Amendment rights, the Government has the burden of establishing that its interests are legitimate and compelling and that the incidental infringement upon First Amendment rights is no greater than is essential to vindicate its subordinating interests." 145

Although the court acknowledged that the Government had a "com-

142. T. EMERson, supra note 4, at 275 .

It seems clear that the First Amendment interest is, if anything, stronger when protected spech or association is sought to be used against a defendant in a criminal trial than it is in the case of forced disclosure of political views before a legislative committe. In the latter case, the First Amendment interest lies in insulating the witness or persons named by the witness from "public stigma, scorn and obloquy" based on the nature of their views or associations, and in avoiding the "more subtle and immeasurable" dampening effect that forced disclosure may have on others. Watkins v. United States, 354 U.S. 178, 197 (1957). Both of those dangers are present when evidence of a defendant's views is introduced in a criminal trial, in addition to the more serious danger that the jury may use those views impermissibly to convict the defendant. Thus the increased strength of the First Amendment interest offsets what may be argued to be the government's greater interest in convicting a criminal defendant.

143. 466 F.2d 1059 (9th Cir. 1972).

144. Id. at 1082 .

145. Id. at 1083 .

The court stated further:

When the collision occurs in the context of a grand jury investigation, the Government's burden is not met unless it establishes that the Government's interest in the subject matter of the investigation is "immediate, substantial, and subordinating," that there is a "substantial connection" between the information it seeks to have the witness compelled to supply and the overriding governmental interest in the subject matter of the investigation, and that the means of obtaining the information is not Id. 
pelling interest" in the general subject of the investigation, ${ }^{146}$ it imposed a more rigorous form of scrutiny, in effect requiring that the Government show a compelling need for the specific information sought by the question at issue: "[ $t]$ he fact alone that the Government has a compelling interest in the subject matter of a grand jury investigation does not establish that it has any compelling need for the answers to any specific questions."147 Applying this test, the court found that the Government had failed to carry its burden with respect to certain questions about the personnel and organization of the Black Panther newspaper ${ }^{148}$ and about the foreign travel of members of the Black Panther Party. ${ }^{149}$ Bursey thus recognized a First Amendment privilege that insulates evidence of protected speech and association from disclosure before a grand jury unless the government can overcome a substantial adverse presumption. . $^{150}$

As in the case of legislative investigations, the First Amendment interests favoring exclusion of a defendant's protected speech at trial seem substantially stronger than the interests favoring exclusion of similar material from consideration by the grand jury. The risk of an improper conviction based on protected speech places a significantly heavier burden on First Amendment interests than the risk

146. Id. at 1086 .

147. Id. (emphasis added).

148. Id. at 1087 .

149. Id. at 1088 .

150. In a case decided after the initial opinion in Bursey, the Supreme Court rejected arguments that the First Amendment insulated certain reporters from testifying before grand juries. Branzburg v. Hayes, 408 U.S. 665 (1972). However, several distinctions between the claim rejected in Branzburg and the First Amendment limitation proposed here should be noted. In Branzburg the reporters asserted a First Amendment privilege against testifying before grand juries even about criminal acts that they saw being committed. The First Amendment limitations on trial testimony proposed here concern only evidence of the defendant's protected speech or association, where much different First Amendment interests are at issue. Furthermore, Branzburg rested in part on the Court's unwillingness to create a First Amendment privilege based on the status of the individual asserting it-a privilege belonging only to news-gatherers and not to others, 408 U.S. at 703-05-together with the fear that such a privilege would create "a private system of informers operated by the press to report on criminal conduct," which would be "unaccountable to the public" and protected by "a virtually impenetrable constitutional shield." Id. at 697. These objections, of course, are inapplicable to the rule proposed here. Finally, the First Amendment interest to be protected here is the defendant's powerful interest in not being punished for his own protected speech or association, rather than the less differentiated, less immediate, and less personal interest of reporters in protecting what is perceived to be the flow of news to others.

After the decision of the Supreme Court in Branzburg, the Government petitioned for rehearing in Bursey; the Government argued that the Court had undercut the basis of the First Amendment privilege asserted in Bursey. Bursey v. United States, 466 F.2d I059, 1090 (9th Cir. 1972). The court of appeals rejected the Government's position, and noted substantial distinctions between the First Amendment rights recognized in Bursey and the privilege rejected in Branzburg. Id. at 1090-91. 
of governmental harassment taking uncertain forms, which was the burden apparently feared in Bursey. Even if the risk in disclosure before the grand jury is thought to be improper indictment on the basis of protected speech, that danger, although severe, is of course not as serious as improper conviction based on protected speech. ${ }^{\mathbf{1 5 1}}$

\section{The Application of the First Amendment Test}

Several additional aspects of the evidentiary test proposed here require mention. In the application of the test at trial, the initial focus must be on the issue of possible First Amendment prejudice. Thus in order for the test to be applicable at all, there must be some danger that prejudice arising from the admission of evidence of the defendant's protected speech or association will violate the defendant's First Amendment rights. This point is worth noting because, in a certain sense, almost any statement of a criminal defendant is "protected" by the First Amendment. That is, if $A$ says to $B$, "I hate $C$ " or "I shot $C$," the First Amendment ordinarily protects $A$ from being punished for having made those statements: the speaking of those words could not, in itself, be made a crime. Nonetheless, $B$ may ordinarily testify at the trial of $A$ for allegedly shooting $C$ that $A$ made those statements. ${ }^{152}$ The test proposed here, however, would have no application in these instances, since there is no substantial chance that the defendant's First Amendment rights would be prejudicedthat is to say, no substantial chance that the protected speech itself would be punished or that impermissibly strong inferences would be drawn from evidence of the speech. ${ }^{153}$ Since the purpose of the test is the protection of First Amendment rights, however, the court should

151. Further, of course, the interest in associational anonymity is partially protected in grand jury proceedings-associations are revealed to the government, but ordinarily not to the public at large-whereas testimony at trial will result in public revelation of political associations. It should also be noted that, in a number of constitutional areas, rules of admissibility in a criminal trial are substantially more restrictive than rules concerning the admissibility of the same evidence before a grand jury. E.g., United States v. Calandra, 414 U.S. 338, 349-52 (1974) (illegally seized evidence, inadmissible at trial, may permissibly be introduced before a grand jury).

152. In the first example ("I hate $C^{\prime \prime}$ ), the evidence may be admissible for the purpose of showing $A$ 's state of mind (hatred of $C$ ) from which the act of shooting $C$ might be inferred; in the second example ("I shot $C$ "), the statement is an admission of the act itself.

153. Without more, there is no substantial likelihood that the jury may punish people who say "I hate $C$ " or "I shot $C$ " merely for having said those words or even, in the situation posed in the first example, for hating $C$. In the second example ("I shot $C^{\prime \prime}$, the possibility that a jury may give a defendant's confession more weight than it should be given-for example, because of coercive interrogation or unusual suggestibility of the defendant-raises separate problems of due process or compulsory self-incrimination. 
give the defendant substantial leeway in asserting the possibility of First Amendment prejudice, and, in a reversal of Judge Weinstein's suggestion, ${ }^{154}$ the possibility of prejudice should be assessed at its maximum reasonable value. ${ }^{155}$ Since political speech is at the core of the First Amendment, the permissible interest of the government in introducing such evidence should be determined with the most scrupulous exactitude.

Once it is shown that there is a risk of First Amendment prejudice, how should the test be applied? First, it will be necessary to be clear on the proposed use of the evidence. Unlike the process employed in Rosenberg, the trial court should indicate with consistency and clarity the precise logical relationship between the evidence in question and the specific element or elements of the offense to which the evidence is relevant. Further, the court should analyze the strength of the inference to be drawn from the evidence to the element or elements of the offense in question and then decide whether the government's interest in introducing the evidence for this permissible purpose substantially outweighs the risk of First Amendment prejudice presented. If there is any substantial danger of prejudice to First Amendment interests, the evidence should be excluded unless the permissible inference from the evidence is extremely strong-since otherwise the probative value would not substantially outweigh the danger of prejudice. ${ }^{506}$ Since limiting or corrective instructions are ineffective as a prophylactic technique, evidence of protected speech or association not meeting the First Amendment test must be excluded-that is, actually withheld from the jury-rather than admitted subject to any sort of limiting instruction. ${ }^{157}$

154. See p. 1660 \& note 134 supra.

155. Although the assessment of prejudice in the relevant community ordinarily involves a form of judicial notice, the defendant should be permitted to introduce specific evidence of prejudice if necessary.

156. Furthermore, in determining the probative value of the evidence, the court should consider the extent to which the government can establish the point in question by means that do not endanger First Amendment interests. Under the proposed test, as under traditional tests, the probative value of evidence to be weighed against prejudicial dangers should be the "incremental probative value"-that is, the probative value added by the disputed evidence to that of nonprejudicial evidence present in the case. See, e.g., Dolan, supra note 13 , at $250-53$. If the point can be substantially proved by nonprejudicial evidence, the incremental probative value of the evidence of protected expression would be significantly diminished.

157. In light of the severe dangers of prejudice presented, and in light of the fact that instructions to the jury to disregard prejudicial evidence are ordinarily ineffective, it seems likely that certain ancillary procedural changes may be necessary in order to assure effective administration of the First Amendment test at trial. Even the prejudice caused by asking a question about the defendant's protected speech or association should be avoided, notwithstanding the fact that if the defendant's objection to the question is 
Finally, when reviewing exercises of the proposed test, appellate courts should abandon the broad deference ordinarily granted to the determination of a trial judge in admitting or excluding evidence. Rather, since First Amendment rights are threatened, the reviewing court should make its own independent determination of whether the test is met. The appellate court should reverse if it finds that the government's permissible interest in the admission of the evidence does not substantially outweigh the danger of First Amendment prejudice. This de novo review would resemble the heightened standard of evidentiary review under the strictissimi juris doctrine in Smith Act and similar litigation, ${ }^{158}$ and would also parallel the Court's practice of directly reviewing factual determinations upon which First Amendment and other constitutional rights depend. ${ }^{159}$

Even with a careful and articulate balancing of probative value and prejudical danger, however, the proposed evidentiary test is subject to flexibility in application, which poses dangers to the protection of First Amendment interests. ${ }^{160}$ Although the test places a substantial burden on the government, the determination of whether the burden is met depends upon an assessment of numerous disparate factors, and the weight to be accorded each factor may vary widely in accordance with the personal judgment of individuals. Thus although the test contemplates a balancing in each case, it may be valuable to outline with greater specificity some suggestions concerning the manner in which the balance might ordinarily be struck with respect to certain common classes of inferences drawn from evidence of speech or association. The following discussion is not intended as a detailed code, but rather as a set of guidelines indicating the manner in

sustained, the information will not be introduced. A similar danger of prejudice is presented by a prosecutor's reference to evidence of protected speech or association in an opening statement if the evidence is later held to be inadmissible at trial. It may therefore be necessary to employ procedural rules that require disclosure before trial of the prosecution's intention to introduce evidence of defendant's political speech or association, in order to obtain a pretrial ruling on the extent to which such evidence may be admissible. This technique may involve a greater use of pretrial practice than is customary in criminal litigation in many jurisdictions, and may also have the effect of requiring the government to reveal more information about the nature of its case than may presently be required under typical criminal discovery rules. Here, as elsewhere, First Amendment imperatives should require the construction of special procedural rules in order fully to safeguard "substantive" First Amendment rights.

158. See, e.g., Noto v. United States, 367 U.S. 290 (1961); United States v. Spock, 416 F.2d 165 (lst Cir. 1969).

159. See, e.g., New York Times Co. v. Sullivan, 376 U.S. 254 (1964); Yates v. United States, 354 U.S. 298 (1957).

160. See, e.g., Branzburg v. Hayes, 408 U.S. 665, 720 (1972) (Douglas, J., dissenting). 
which the specific problems set forth below should ordinarily be approached. ${ }^{161}$

1. Inferences from defendant's speech to his state of mind or action. The inference from an individual's speech to his subsequent action is often weak. Generally such an inference requires an intermediate inference as to the speaker's state of mind: the sequence proceeds from (1) the words of the speaker, to (2) an inference that the speaker possessed a certain state of mind, to (3) the further inference that the speaker acted in accordance with that state of mind. If a court admits $A$ 's statement, "I intend to kill $B$," for the purpose of showing that $A$ killed $B$, the jury must draw an inference from the words to the fact that $A$ actually intended to kill $B$ (since it is possible that $A$ was joking or exaggerating), and from that intention to the fact that $A$ killed $B$. The latter inference may be the most difficult, since the performance of intended acts frequently does not occur.

In the foregoing example, the inference from the defendant's speech to his action is arguably at its strongest, since the first inferential step, from words to intention, is as clear as it can be made. The inference is substantially more problematic if the defendant's statement is not an assertion that he possesses the intention to perform the very act in question. If $A$ 's statement is "I hate $B$," for example, the inference is substantially more tenuous. We still have the problem of inferring a state of mind ("hatred") from the words. Does $A$ really "hate" $B$, or was he merely exaggerating a momentary annoyance? Here also, however, the jury must then proceed to infer $A$ 's intention to kill $B$ from $A$ 's "hatred" of $B$. This is the more difficult step, because the jury has no clear indication of what "hatred" means to this

161. Although these suggestions are not offered as absolute per se rules, it is possible that the suggested results will so often be correct that the loss of flexibility in their adoption will be outweighed by the greater certainty that First Amendment interests will be protected in judicial decisions. A similar judgment, for example, may well underlic the application of the per se rules of Miranda $v$. Arizona, 384 U.S. 436 (1966), as evidentiary safeguards for Fifth Amendment rights. Although the case-by-case determination of "voluntariness" may have most closely reflected the "true" Fifth Amendment test for confessions, the perceived likelihood that courts were erroneously admitting as "voluntary" a significant number of "involuntary" confessions may have led in part to the creation of prophylactic per se rules intended to reduce the number of Fifth Amendment violations through a test that could be administered with greater ease and clarity by appellate courts. See Kamisar, $A$ Dissent from the Miranda Dissents: Some Comments on the "New" Fifth Amendment and the Old "Voluntariness" Test, 65 Mrch. L. Rrv. 59, 94-104 (1966); Monaghan, The Supreme Court, 197f Term-Foreword: Conslitulional Common Law, 89 Harv. L. Rev. 1, $20-23$ (1975). See also Gertz v. Robert Welch, Inc., 418 U.S. 323, 343-44 (1974) (case-by-case balancing in review of libel judgments rejected bccause "this approach would lead to unpredictable results and uncertain expectations, and it could render our duty to supervise the lower courts unmanageable"). 
particular individual and therefore must be unclear on the strength of the inference from "hatred" of $B$ to intention to kill $B .{ }^{162}$

The difficulty is greatly exacerbated when the words from which an inference of action is to be drawn constitute political speech protected by the First Amendment, particularly general political commentary on governmental systems or forms. The basic problem lies in the remoteness of the inference from general political commentary to the performance of a specific illegal act and in the peculiar dangers of prejudice arising from the introduction of such a statement when the political views in question are offensive to majority opinion.

Suppose, to adapt an example from the Rosenberg case, the defendant in an espionage case has said, "I prefer the form of government of the Soviet Union to the form of government of the United States." Such a statement concerning political forms tells us very little about the speaker's intention to commit espionage on behalf of the Soviet Union. The inference is particularly weak because the speech of the defendant is commentary on political affairs. Since political speech is frequently exaggerated and polemical in quality, ${ }^{163}$ the initial inference from the words to a state of mind (the actual preference for the form of government of the Soviet Union) may be particularly tenuous. As noted above there is the additional problem of drawing an inference from the defendant's preference for a certain form of government to his preference for the nation possessing that form of government. ${ }^{164}$ There is then the further difficulty of inferring a fully formed intention to commit espionage for that country and the final problem of inferring action from such an intention. This is not to say that the evidence of such political statements is not relevant to show action, but rather that the inference from speech to action is weak in general and particularly weak when the inference to be drawn is from general political speech to illegal action. Even though the inference from general political views to action is weak, it is likely to be endowed with undue strength in times of political stress by those who equate unorthodox statements with treasonous or seditious intent. ${ }^{105}$

162. In this instance, of course, the same problems also remain with respect to the inference from the state of mind (intention of killing $B$ ) to the act itself.

163. See, e.g., New York Times Co. v. Sullivan, 376 U.S. 254, 271-72 (1964); Cantwell v. Connecticut, 310 U.S. 296, 310 (1940). See also T. EMERson, supra note 4, at 125 ("The language of politics is filled with terms borrowed from the field of battle and violence, and careful distinction between symbolic and realistic expression, uttered in the heat of controversy, might not be drawn.")

164. See p. 1636 \& note 41 supra.

165. When a defendant's prior speech is described in court by a witness, another significant problem arises. Not only is it possible that the jury will draw an unduly strong inference of action from the defendant's words, as reported by the witness, but 
In consequence, statements of a defendant's general political views or preferences-particularly statements concerning political systems or forms-should ordinarily be inadmissible for the purpose of giving rise to an inference that the defendant committed certain acts supposedly in consonance with those views. This should especially be the result so long as there is any substantial hostility in the community toward the views in question. Although the statements may have some probative value for the purpose offered, the inference is tenuous and remote and rarely sufficient to override the severe prejudicial dangers arising from the disclosure of unpopular views.

It is possible, however, that in some instances more narrowly focused and specific statements, bearing on a possible intention to act, may have substantially more probative value than statements of general political views. Such statements, therefore, may not necessarily be excluded under the guideline proposed here, even though they are perhaps prompted by general political views. In assessing the admissibility of speech on the question of a defendant's action, it may thus be necessary to draw a line separating general political views from views of greater specificity bearing on the alleged offense. ${ }^{166}$

Somewhat wider scope might also be given to the use of evidence of a defendant's protected speech for the sole purpose of showing his

also the wilness himself may be influenced by the unorthodox nature of the views expressed and thus may be led to exaggerate the specific evil of the language he has heard. The witness, however, may be completely unaware of his own uncertainties or exaggerations.

166. Thus in a prosecution for espionage on behalf of the Soviet Union, statements that the defendant prefers the Soviet form of government should ordinarily be cxcluded. However, statements that any steps are justifiable to further the goals of the Soviet Union might not necessarily be excluded under the position suggested here. Similarly, in the prosecution of defendants for the alleged random shooting of white people, the defendants' remarks that white people are oppressors and "devils" should ordinarily be excluded, as general political statements. On the other hand, statements by defendants approving violence against white people may not necessarily be excluded under the proposed test even if the statements constitute protected speech.

Due to the problem of accurately reporting precisely what the defendant has said, the First Amendment test should require that the contents of such specific statements of intention be established by particularly convincing proof. The test might require, for example, that the defendant's statements have been made in written form, or that a witness testifying to oral statements have some particularly persuasive reason for remembering the precise form of words that was used. Another variable that must be taken into account in applying the test in this area is the possibility that language that appears to be of greater specificity bearing on the alleged offense may actually be little more than exaggerated rhetoric, in reality reflecting general political views rather than the intent apparently set forth in the language. See, e.g., Watts v. United States, 394 U.S. 705 (1969). In the application of the test, therefore, the court must assess whether or not the defendant's statements were made under circumstances in which they appear to be a literal reflection of the defendant's actual state of mind. Thus, remarks made in the excitement of a large public rally may have less weight in this connection than the same comments made deliberately in a small private gathering. 
intent as a separate element of the offense. Thus, when the performance of an act has been conceded by the defendant and when the case turns on the question of the intent with which the act was performed, the government might be able to show an overriding interest in the use of evidence of protected speech to establish such intent, even though it would not have been permitted to use such evidence to give rise to an inference that the defendant committed the act in question. The inference from speech to intent is a much stronger inference than the inference from speech to action, since in the former instance fewer inferential steps are necessary and the difficult step from intent to action is not at issue. ${ }^{\mathbf{1 6 7}}$ Greater liberality in proof of intent might also be premised on the difficulty of inferring intent from ambiguous acts when intent is an essential element of the offense. ${ }^{168}$ No one can read the mind of the actor, and speech is often the only (or at least the clearest) evidence bearing on the question of intent. Acts exist in the physical world and thus are more clearly susceptible of external proof. ${ }^{169}$

167. Similarly, evidence of other crimes has traditionally been admitted more freely to show that defendant possessed a certain state of mind than to show that defendant committed a certain act. See, e.g., Jones v. Commonwealth, 303 Ky. 666, 198 S.W.2d 969 (1947). Even when proving intent alone, however, it should be remembered that the dangers of First Amendment prejudice may be severe. Further, any more liberal use of such evidence to show intent (as a separate element of the offense) should generally be limited to instances in which the performance of the act has been conceded by the defendant. If the evidence were introduced for the purpose of showing intent alone in a case in which the defendant's performance of the act was also at issue, the jury would most likely use the evidence to give rise to the more questionable inference of action, regardless of any limiting instructions. In such a case, therefore, the evidence should not be admitted on the question of intent unless the government can show that the First Amendment test is also met with respect to the Government's proposed use of the evidence on the issue of defendant's action. Also, wider scope for proof of intent should not be permitted in conspiracy prosecutions, where the entire offense may be cast in terms of intent and where the looseness of the definition of the offense tends to place First Amendment interests at a substantial disadvantage. See generally Filvaroff, Conspiracy and the First Amendment, 121 U. P. L. Rev. 189, 198-201, 250-53 (1972); Note, Conspiracy and the First Amendment, 79 YALE L.J. 872 (1970).

168. Compare, e.g., the traditional hearsay exception granting wide admissibility to evidence of a declarant's statements when used to prove his intent or other state of mind. FED. R. EvID. 803(3).

169. A useful example of evidence used to show intent is suggested by Professor Emerson, who remarks that "a speech urging the blocking of traffic on a bridge in protest of the Vietnam war might be introduced in proof of the state of mind of the speaker when his car later stalled on the bridge." T. EMErsos, supra note 4, at 406 . Under the analysis suggested here, evidence of this speech might possibly be admitted, cven if constitutionally protected, as the government may have an overriding interest in the introduction of the evidence to show intent in light of its high probative value on that issue, resulting from the specificity of the remarks. This argument might perhaps also apply to remarks that were not quite so clearly exhortations-such as public statements that "this war will only be ended if roads and bridges are shut down." It should be noted, however, that this evidence is nonetheless suspect, even if used for the purpose of showing intent only and the First Amendment test must, at any rate, be applied to 
2. Inferences from the speech of a third person to defendant's state of mind or action. On occasion the prosecution may seek to introduce evidence of the protected speech of a third person or persons in order to give rise to an inference that the defendant possessed a certain intent or performed certain illegal actions. The prosecution, for example, may seek to impute to the defendant the views of a book that he has read or that he possesses-either through independent evidence or as an inference from the fact of possession itself-to give rise to the further inference that the defendant acted in accordance with ideas expressed in the work. ${ }^{170}$ In this instance the introduction of the evidence of protected speech may infringe the First Amendment rights of the defendant as a member of the "audience,"171 rather than the defendant's rights as speaker, although the two rights are most sensibly viewed as two aspects of the more general right of freedom of thought or belief. ${ }^{172}$ Clearly, however, a defendant's First Amendment rights are violated if he is convicted on the basis of impermissible inferences drawn from the ideas contained in books he has read or movies he has seen. ${ }^{173}$

The inference from a third person's speech to the action of the defendant is, in general, substantially more tenuous than the inference from the defendant's own speech to his action. If, for example, evidence is introduced that the defendant read or possessed a book containing statements urging violence against policemen, the inference that the defendant took certain action, such as assaulting a policeman, is substantially more remote than the inference to be drawn from the defendant's own statements urging or endorsing such violence. Even if the work contains such exhortations to action, its probative force must rest on the difficult inference that the defendant

the specific circumstances of the trial. For example, if the state has other evidence of the defendant's intent, not in the form of political speech-such as the defendant's obstruction of policemen in their attempts to move the car-the evidence of protected speech might be excluded due to its diminished incremental probative value. See note 156 supra.

170. See note 4 supra (introduction of film and books in Panther 21 and Angela Davis trials).

171. See Virginia State Bd. of Pharmacy v. Virginia Citizens Consumer Council, Inc., 425 U.S. 748, 756 (1976); Stanley v. Georgia, 394 U.S. 557, 564 (1969).

172. Kleindienst v. Mandel, 408 U.S. 753, 775 (1972) (Marshall, J., dissenting).

173. Prejudicial uses of such evidence parallel improper uses of evidence of a defendant's own speech. For example, the jury may wish to punish a defendant for reading the literature in question (and, by implication, for having the interests and beliefs suggested by the literature), totally apart from any relation between the literature and the offense for which the defendant is being charged. Further, a jury may irrationally infer that anyone who reads particular literature is likely to have committed crimes in general, or may improperly endow a tenable but remote inference from literature to a reader's action with a strength that the inference cannot rationally be found to possess. 
was persuaded by the particular statements in question, out of all statements in the book, and in effect adopted as his own the intent revealed in the exhortation. Frequently, however, people read literature containing views with which they do not agree for the purposes of study, refutation, or curiosity.

When the statements in the work or speech of another are general political remarks rather than narrow and focused exhortations, the inference becomes even more dubious. The jury must then infer not only that the defendant agreed with the statements, but also that the general political views thus revealed led the defendant to conceive an intention to perform a specific act, an inference which, as we have seen, is very difficult to draw from general political language, even when the language is the language of the defendant and not of some third person.

Even though the inference is in reality exceedingly remote, however, the possession of unpopular literature may well lead to substantial prejudice in the form of unduly strong inferences of criminality. If there is any substantial risk of prejudice, therefore, the First Amendment should ordinarily be held to prohibit any inference to a defendant's state of mind or action drawn from evidence that he read or possessed a particular work pertaining to public affairs. If there is clear extrinsic evidence that a defendant adopted a specific statement of a third person as his own, the statement should then be considered under the guidelines for evidence of a defendant's own statements, set forth above.

3. Inferences from defendanl's political association. The introduction of evidence of a defendant's political association to give rise to an inference of his state of mind or action can be viewed as a special and more complicated instance of the introduction of statements of third persons for the same purpose. Evidence of political association is ordinarily introduced to impute to the defendant certain tenets of the association, as articulated by persons other than the defendant. The evidence might then give rise to the further inference that the defendant possessed a certain intent supposedly in accordance with those tenets and perhaps that the defendant acted in accordance with that intent. ${ }^{174}$ As with any use of third party statements to draw an

17.4. The basic problem is two-fold: first, there is the question whether statements of specified third parties can be attributed to the organization; second, even if the organization can be said to possess certain tenets, there is the question whether, or to what extent, the tenets can be attributed to the defendant. The Supreme Court has stressed analytical difficultics inherent in imputing the views of third persons to a specified 
inference as to defendant's own intent or action, the basic question concerns the extent to which it may be concluded that the defendant has adopted the third party's tenets as his own. Of course one ordinarily joins a political organization because of agreement with some of its tenets. But courts have recognized that political parties and other political groups that possess some illegal goals often also possess legal goals and that a member of such a group may intend to further its legal goals only. ${ }^{175} \mathrm{If}$, as the court of appeals assumed in United States v. Rosenberg, evidence of Communist Party membership is introduced to give rise to an inference that the defendant committed acts of espionage, ${ }^{176}$ the jury is permitted to draw an inference of illegal intent (and, hence, of illegal action) when the defendant may have belonged to the party solely with the intention of furthering its legal goals. In light of the ambiguity inherent in membership in a group that possesses both legal and illegal goals, the inference from membership to illegal intent or action may be weak. Furthermore, when the organization is highly unpopular there is serious danger that inferences of a member's intent to further the illegal goals of the organization will be drawn with undue strength.

The application of the First Amendment test must therefore focus on the extent to which the evidence of associational membership is ambiguous. When a group possesses substantial legal goals, evidence of membership, with little more, would often be highly ambiguous on the question of defendant's illegal intent. The evidence would thus possess relatively little probative value on the question of the defendant's state of mind or propensity for illegal action. Highly ambiguous evidence ordinarily would not substantially outweigh the prejudicial dangers presented by evidence of connection with an extremely unpopular organization.

It is conceivable, however, that the Government, through the introduction of additional evidence about the organization, might show a very high likelihood that each member of the organization adheres to the illegal goals, in which case the probative value of evidence of association to show a defendant's intent to achieve those goals might rise to the requisite level. Nevertheless, such a course poses its own

organization, Schneiderman v. United States, 320 U.S. 118 (1943), and has also cast doubt on the permissibility of inferring a defendant's individual beliefs and intent from the tenets of an organization with which he may be associated, De Jonge v. Oregon, 299 U.S. 353 (1937).

175. Scales v. United States, 367 U.S. 203 (1961); United States v. Spock, 416 F.2d 165, 169 (1st Cir. 1969).

176. See pp. 1634-35 supra. 
serious dangers to First Amendment interests. In proving such a general proposition about the membership of an organization of any size or complexity, introduction of the amount of evidence necessary to make an adequate showing might well shift the focus of the trial from the specific offense charged to a more general consideration of the nature of the group itself. ${ }^{177}$ This would multiply prejudicial dangers and would risk misleading the jury into believing that the charge against the defendant is proved upon a finding that the organization possesses the goals charged. As a result of these twin dangers, the First Amendment test might be found to preclude the use of associational membership when the prejudicial danger presented by the evidence is high and when the organization is of substantial size and possesses significant legal goals in addition to its alleged illegal goals. ${ }^{178}$ Such a conclusion would not necessarily prevent introduction of evidence of specific statements or activities of the defendant him-

177. Such a showing about any but the smallest organizations would presumably require more evidence than the cursory views of a single witness, such as the testimony of Elizabeth Bentley in United Stales $v$. Rosenberg. See p. 1637 supra.

It might be argued that general evidence of strict discipline within the organization is a sufficient addition to evidence of defendant's membership to permit an inference that defendant was prepared to accomplish, and may have acted to accomplish, any of the goals of the organization, including its illegal goals. In a case in which there is direct evidence showing the amenability of the specific defendant to such discipline, this argument might have some force. But where the only evidence is general testimony as to discipline exercised within the group or specific testimony as to discipline exercised over individuals other than the defendant, the evidence again requires an inference not from defendant's own words or acts to his intent, but rather from the words and activities of third parties to the defendant's intent. The same problems of ambiguity are raised, since there is no direct showing that defendant's specific relationship with the organization is the same as any other individual's relationship; that is, that he, like certain others, is amenable to discipline.

178. A flat prohibition of the use of evidence of association to show intent to further the illegal goals of the organization might be implied by the opinion of the court in United States v. Spock, 416 F.2d 165 (1st Cir. 1969). As discussed above, see p. 1656 and note 120 supra, the court in Spock considered defendants' participation in a "bifarious undertaking," one possessing both legal and illegal goals, and found that it was "improper" to introduce the views of other members of the "undertaking" for the purpose of showing the defendants' proscribed intent. $416 \mathrm{~F} .2 \mathrm{~d}$ at 173 . It is arguable that the strictissimi juris principle, as refined in $S p o c k$, should be viewed as a prohibition against drawing any inference of illegal from evidence of defendant's membership in a "bifarious" undertaking, even if accompanied by evidence of the illegal goals of certain other members. Rather, only direct evidence that the defendant, as an individual, favored the illegal goals of the organization would be permitted. In any kind of litigation, it might be argued, the inference from a bifarious association to a specific member's illegal intent violates First Amendment values since the risk of a burden on rights of asscoiation is unacceptably high if there is any real possibility that the inference from membership to illegal intent may be erroneous. Furthermore, if spock thus implies that an inference of defendant's illegal intent cannot permissibly be drawn from evidence of "bifarious" membership, it should a fortiori be impermissible to allow an inference of defendant's act to be drawn from such evidence, since the inference from membership to an illegal act requires, as a preliminary step, the drawing of the prohibited inference from membership to an intention to accomplish the illcgal goals of the enterprise. 
self, made or undertaken in connection with membership in a political group, which would give rise to an inference of the defendant's own specific intent. ${ }^{178}$

Two final points should be noted with respect to the general application of this First Amendment test. First, the constitutional right at issue is a right of the defendant and can be waived. Consequently, if the defendant wishes to introduce evidence of his own political speech or association, nothing in the proposed test would prohibit him from doing so. It should be understood, however, that the defendant's introduction of such evidence might result in permitting the prosecution to introduce rebutting evidence of the defendant's speech or association, which might otherwise have been inadmissible. ${ }^{180}$ The defendant's introduction of evidence of his protected expression might increase the need for the introduction by the government of its rebutting evidence, a need that did not exist in such compelling form before the defendant's introduction of his evidence. Even under such circumstances, however, care must be taken to limit the amount of evidence that the prosecution is permitted to introduce on this point and also to limit the purpose for which evidence of speech or association might be introduced by the government. The defendant's introduction of certain evidence of protected speech or association should not be held to permit the prosecution to introduce evidence of protected speech or association for purposes extending beyond the purpose for which such evidence was introduced by the defendant.

Further, it should be noted that although the discussion in this article has been limited to the introduction of evidence of protected speech or association in the proof of a nonspeech offense, the same principles should generally be applicable in prosecutions of defendants for incitements or other allegedly unprotected speech. In such prosecutions, of course, the speech that is alleged to be unprotected must be introduced into evidence, since it is the central focus of the prose-

179. Nor would such a result necessarily exclude evidence of specific instructions to commit illegal actions given to the defendant in the organizational context, under circumstances in which it seemed clear that the defendant, as an individual, accepted the instructions. Clearly in such instances the probative value of the evidence is high and its capacity to mislead the jury is relatively low.

180. A defendant charged with murder might introduce evidence showing that his religious beliefs forbade killing. See, e.g., N.Y. Timєs, June 9, 1976, at 16 , col. 1 (persons accused of murdering FBI agents inform jury of tenet of their religion forbidding murder). But see Government of the Virgin Islands v. Petersen, 553 F.2d 324 (3d Cir. 1977) (evidence that murder defendant belonged to religious sect that professes nonviolence excluded as improper character evidence under FED. R. Evid. 405(a)). If such evidence is introduced, the government might not be prohibited from introducing contrary evidence with respect to the religious doctrine in question. 
cution. ${ }^{181}$ In some instances, however, the government may seek to introduce evidence of clearly protected speech or association in addition to the arguably unprotected speech for which the defendant is actually on trial, and questions may arise with respect to whether the protected speech should be allowed into evidence.

In prosecutions for incitement, for example, the government may seek to introduce clearly protected speech that preceded or followed the arguably unprotected remarks. ${ }^{182}$ A certain amount of this speech might conceivably be essential to give content to the allegedly unprotected speech, to explain precisely what that language is alleged to mean, and perhaps to establish the elements of constitutionally unprotected incitement under the test of Brandenburg $v$. Ohio. ${ }^{183}$ More remote speech, however, although perhaps giving further body to the description of the unprotected incitement, should be stringently tested under the principles suggested here. The jury's focus on the specific remarks alleged to be unprotected should not be disturbed by an undue invitation to decide the case on the basis of the general political views propounded by the defendant. Such an invitation clearly becomes more prominent as additional evidence of protected speech is introduced into evidence. The admission of offensive political statements, beyond those clearly necessary to establish the offense, increases the probability that a jury might convict for those offensive statements even though it might not believe that the supposedly unprotected remarks were actually made, or even though it might not have found that the alleged "incitement" was actually punishable under a statute drawn to comply with relevant constitutional tests. The danger of improper jury retaliation is thus clearly present in this context also.

181. Introduction of that evidence raises no issue under the principles suggested here: if the speech is found to be unprotected, no problem arises, and if the speech is found to be protected, the defendant is acquitted.

182. Thus, in a prosecution for incitement by a member of a radical political group, the prosecution might seek to introduce extensive evidence of the general political views of the defendant and of the political group in question, in addition to evidence of the specific language of the defendant alleged to be unprotected and the immediately surrounding circumstances. Cf., e.g., People v. Epton, 19 N.Y.2d 496, 227 N.E.2d 829, 281 N.Y.S.2d 9 (1967), appeal dismissed, 390 U.S. 29 (1968) (views of political group introduced in prosecution for criminal anarchy). Similarly, in a prosecution for incitement to violent action immediately following an anti-war rally, the prosecution might seek to introduce evidence of the specches delivered at the rally. Cf. Brandenburg v. Ohio, 395 U.S. 444,446 (1969) (extensive evidence of offensive speech of defendant introduced in addition to specific remarks apparently thought by prosecution to constitute incitement to unlawful action).

183. 395 U.S. 444, 447 (1969) (per curiam) ("the constitutional guarantees of free speech and free press do not permit a State to forbid or proscribe advocacy of the use of force or of law violation except where such advocacy is directed to inciting or producing imminent lawless action and is likely to incite or produce such action"). 


\section{Conclusion}

In the Rosenberg case, as in many other cases in which evidence of political speech or association has been introduced into evidence, there was significant danger that antipathy toward the defendants' political beliefs may have improperly affected the jury's consideration. The risk of unconstitutional conviction based on protected speech is always present when unpopular political views of criminal defendants are entered into evidence, but the danger is particularly severe in times of political tension such as the Cold War era of the 1950s or the period of social unrest of the late 1960s. Just as litigation arising in periods of political stress has illuminated First Amendment problems in many other areas, the history of criminal trials involving inflammatory political issues reminds us that here, too, the values of the First Amendment are in need of vigilant protection. It has been the purpose of this article to suggest some principles by which First Amendment problems arising in the course of such trials may be resolved. 


\section{The Yale Law Journal}

Volume 86, Number 8, July 1977

Peter J. Kalis
Editor-in-Chief

William N. Eskridge

Note is Topics Editor

Matthew T. Heartney

Edward P. Krugman

Mark C. Rahdert

Note Editors
Richard H. Klapper

Managing Editor

David J. Grais

Charlotte G. Meriwether

David O. Stewart

Article of Book Review

Editors
Scott D. Baskin

David M. Brewer
Michael D. Lowe

Bradley S. Phillips

David M. Skover

Secretaries to the Editors M. Olive Butterfield, Pamela Willmott

\section{Student Contributors to This Issue}

Michael D. Lowe, Contingent Fees for Expert Witnesses in Civil Litigation

Bradley S. Phillips, Limiting the Peremptory Challenge: Representation of Groups on Petit Juries 